\title{
The journey of out-of-school girls in Ethiopia: Examining migration, livelihoods, and HIV
}

Annabel Erulkar

Population Council

Girmay Medhin

Population Council

Lemi Negeri

Population Council

Follow this and additional works at: https://knowledgecommons.popcouncil.org/departments_sbsr-pgy

Part of the Demography, Population, and Ecology Commons, Family, Life Course, and Society Commons, International Public Health Commons, and the Maternal and Child Health Commons How does access to this work benefit you? Let us know!

\section{Recommended Citation}

Erulkar, Annabel, Girmay Medhin, and Lemi Negeri. 2017. "The journey of out-of-school girls in Ethiopia: Examining migration, livelihoods, and HIV." Addis Ababa: Population Council. 


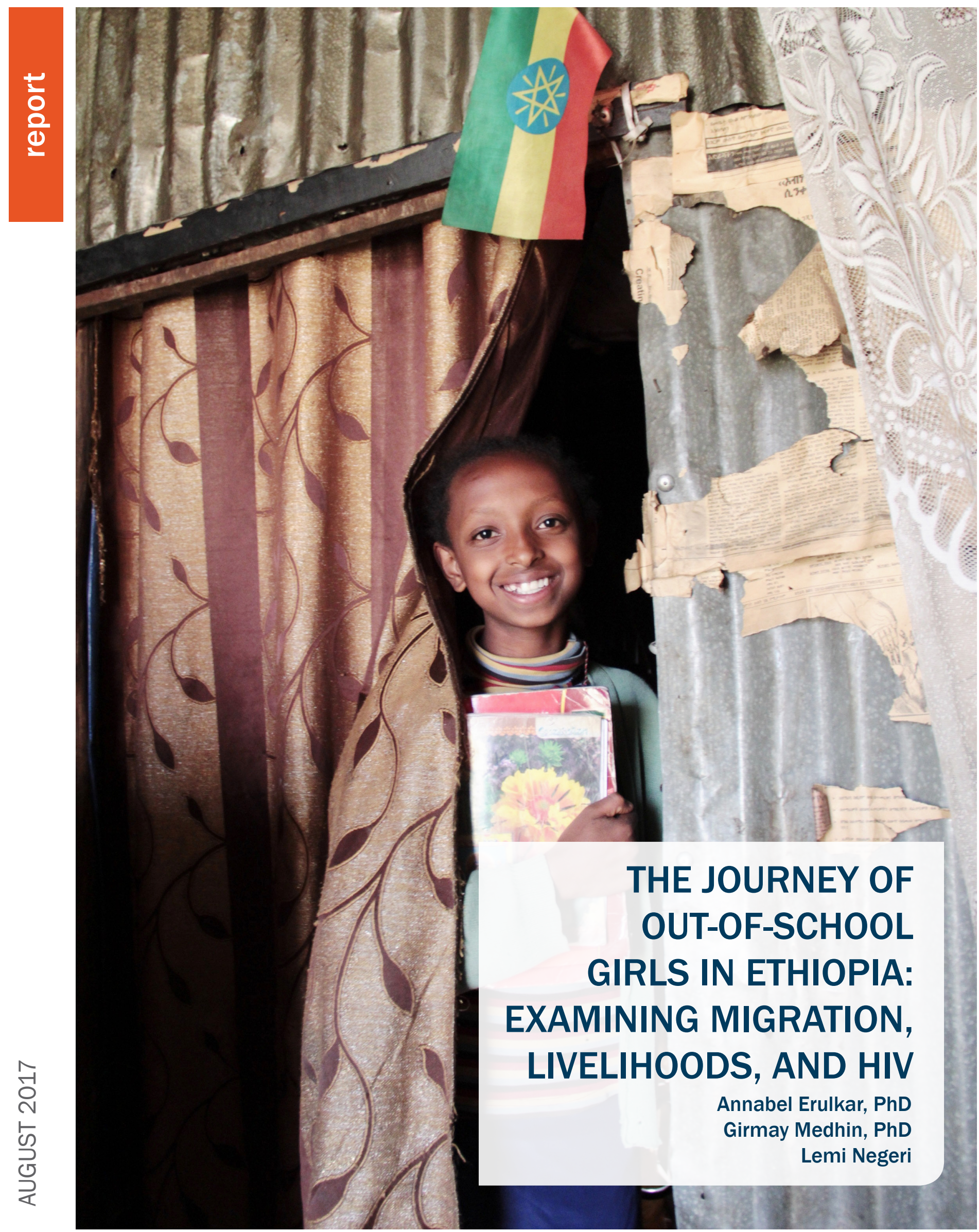

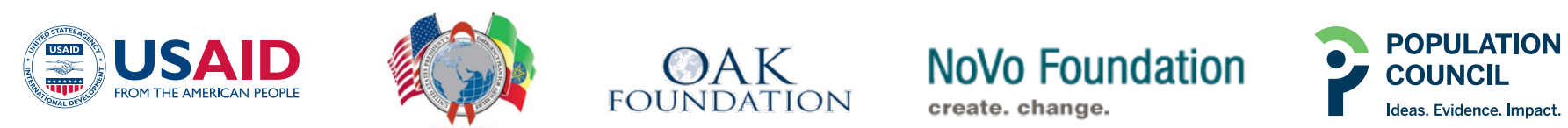


The Population Council confronts critical health and development issues-from stopping the spread of HIV to improving reproductive health and ensuring that young people lead full and productive lives. Through biomedical, social science, and public health research in 50 countries, we work with our partners to deliver solutions that lead to more effective policies, programs, and technologies that improve lives around the world. Established in 1952 and headquartered in New York, the Council is a nongovernmental, nonprofit organization governed by an international board of trustees.

\section{Population Council}

Heritage Plaza, 4th Floor

Bole Medhalialem Road

P.O. Box 25562, code 1000

Addis Ababa, ETHIOPIA

Tel: +251-116-631-712/4/6

email: info.ethiopia@popcouncil.org

popcouncil.org

Suggested citation: Erulkar, Annabel, Girmay Medhin, and Lemi Negeri. 2017. "The Journey of Out-of-School Girls in Ethiopia: Examining Migration, Livelihoods, and HIV.” Addis Ababa: Population Council.

Photo credits: Zeleman Productions, Dhaniel Negatu

(C) 2017 The Population Council, Inc.
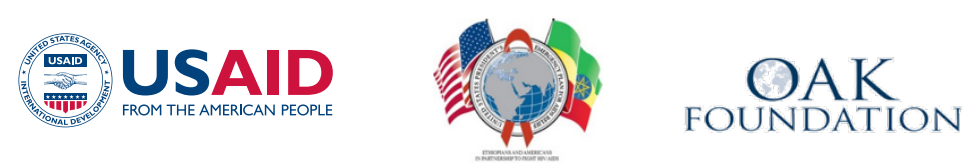

NoVo Foundation

create. change.

This study was made possible by the generous support of the American people through the United States Agency for International Development - President's Emergency Plan for AIDS Relief (USAID-PEPFAR), the Oak Foundation, and the NoVo Foundation. The contents are the responsibility of the authors and do not necessarily reflect the views of USAID or the United States Government, or of the Oak or Novo Foundations. 


\section{Table of Contents}

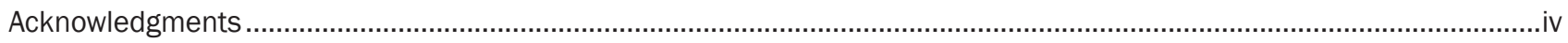

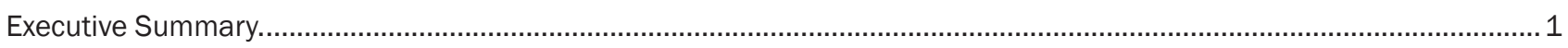

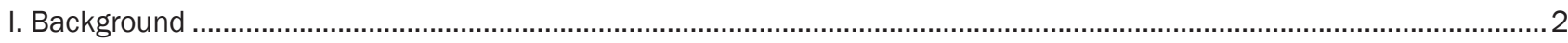

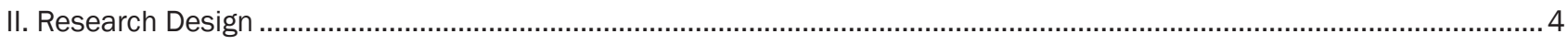

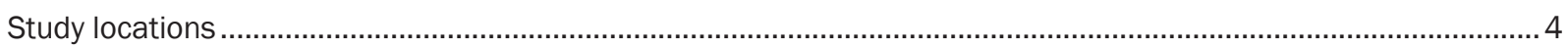

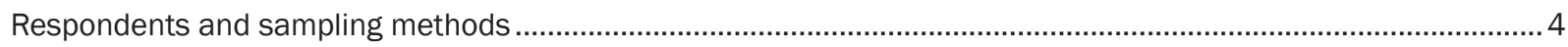

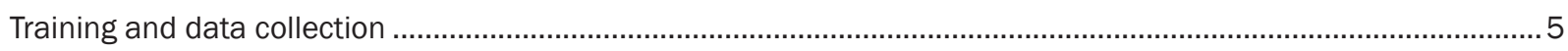

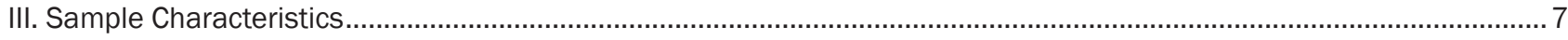

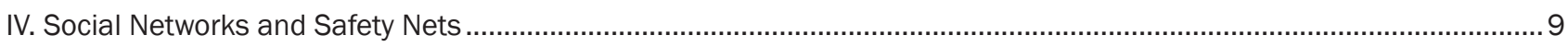

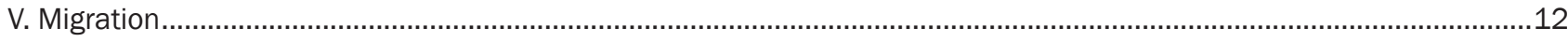

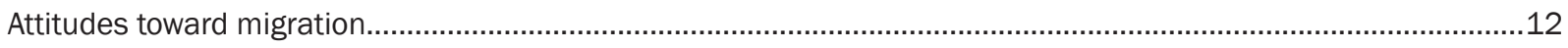

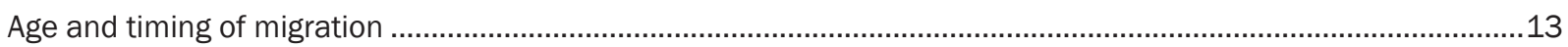

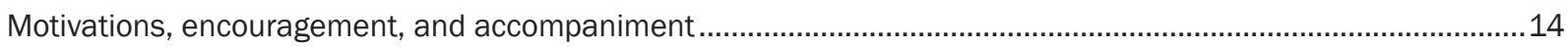

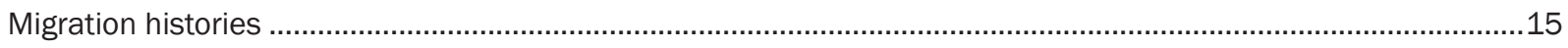

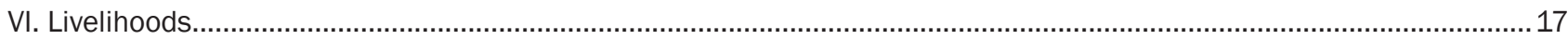

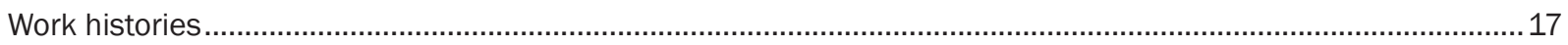

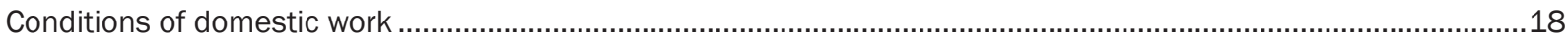

Entry into commercial sex work/commercial sexual exploitation ......................................................................19

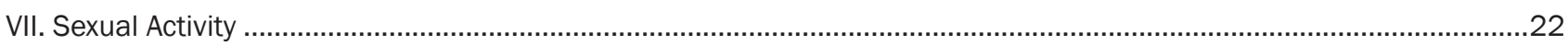

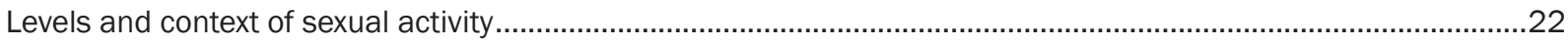

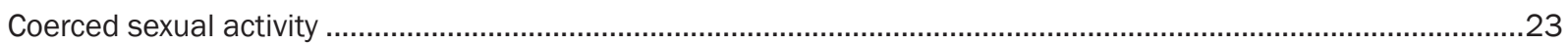

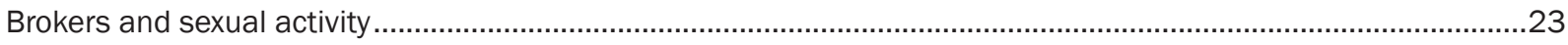

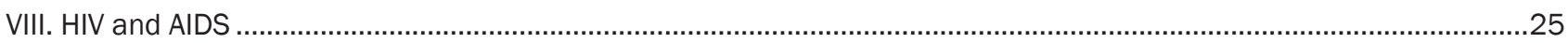

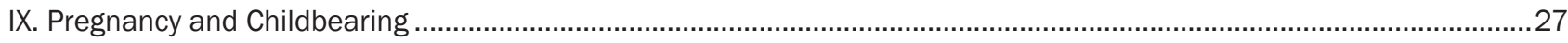

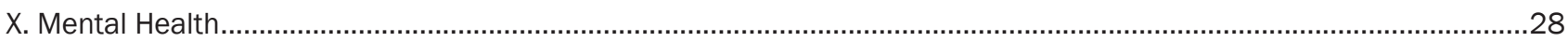

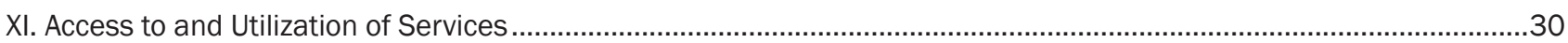

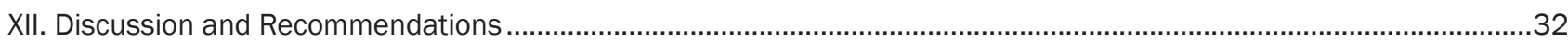

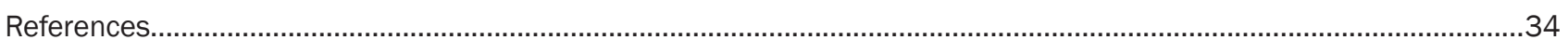




\title{
Acknowledgments
}

\begin{abstract}
A large number of collaborators contributed to this study. We are grateful to the Federal Ministry of Youth and Sports and to Youth and Sport Offices in the study sites for support, guidance, and collaboration. We are indebted to our donors USAID/PEPFAR, Oak Foundation, and NoVo Foundation for seeing the importance of this work and investing in research on adolescent girls. A great many specialists and experts supported this work, including Dr. Getnet Tadelle, Mr. Mebratu Gebeyehu, and Ms. Helen Amdemikael. Population Council staff and former staff worked tirelessly on this effort, including (in alphabetical order): Genework Daba, Habtamu Demele, Frehiwott Getachew, Getachew Kassa, Hanan Nourhussein, Amanda Speigelberg, and Helen Tessema. We are indebted to the tireless efforts of many interviewers, supervisors, coordinators, transcribers, serializers, and data-entry staff. Sarah Engebretsen, Judith Bruce, Thoai Ngo, and Kidist Belete made very helpful comments on the draft report. Throughout the study, staff from USAID guided the process, including Renee DeMarco, Chalachew Tiruneh, Sophia Brewer, and Kidist Belete. Finally, we are grateful to all the girls in six regions of Ethiopia who gave us their time, shared their views, and described their experiences. We are hopeful that this research can make a difference in the lives of girls in Ethiopia and beyond.
\end{abstract}




\section{Executive Summary}

Rates of urbanization in Ethiopia are increasing, and out-of-school adolescent girls and young women are the largest groups of individuals to migrate. Based on available data, HIV prevalence among urban girls who are in-migrants is significantly higher than among girls who are native to the area. Likewise, a significant number of out-of-school girls who migrate end up in low-status, exploitative, or risky professions, such as domestic work and sex work. Yet little research in Ethiopia has been devoted to the experience of out-of-school girls' migration, livelihoods, and HIV risk.

This is a study of out-of-school girls in six regions of Ethiopia, undertaken in both urban and rural areas of the country. Rural parents and brokers who channel girls into different forms of work were also interviewed. The study aimed to explore patterns of migration, transitions into different work roles, and situations that may put out-of-school migrant girls at increased risk of HIV infection or be protective and beneficial. The study included both qualitative and quantitative research. In the first phase, qualitative, in-depth interviews were conducted among 143 respondents including domestic workers, sex workers, other out-of-school migrant girls, parents, and brokers. In the second phase, quantitative survey data was collected from 5,272 out-of-school girls, as well as 668 parents and 270 brokers.

On average, out-of-school girls migrated at age 14, frequently as a result of hastily made decisions and little planning. Most often, they migrated on their own, with a distant relative, or with a friend/acquaintance. Consistent with other studies, step migration-or migration in stages from rural areas to small towns to bigger towns-is not as common among out-of-school girls as is assumed. Migration marks abrupt changes to girls' schooling and livelihoods status, with most not attending school following the move but entering paid work. The most common paid work upon arrival to the city was domestic work, followed by work in a restaurant or café. These were also the lowest paid jobs, with domestic workers earning an average of 495 Ethiopian Birr (US\$22) per month. However, those entering domestic work did not stay in the profession. Many out-of-school girls subsequently tran- sitioned into restaurant work or sex work, with the latter profession earning considerably more than domestic work (an average of 3,524 Ethiopia Birr per month or US\$160). After exiting domestic work, many girls described sexual and physical abuse while in this profession. Few current domestic workers reported such abuse, perhaps because of fear of retaliation or fear of losing their jobs and accommodations.

Brokers place out-of-school girls in a range of professions, including domestic work, the service industry, and sex work. More than one in five brokers reported having sex with girls who they encountered. Many reported that it was the girl's first time to have sex and many took advantage of the fact that the girl had no place to stay.

As a result, researchers recommend expanding upstream programs for out-of-school girls, before they transition into sex work. This could include expansion of programs for domestic workers and other migrating girls. Programming targeted at the time of school-leaving or migration will support particular points of vulnerability for girls. Strategies to channel out-of-school girls into productive and safe livelihoods should be further explored. 


\section{Background}

Ethiopia is a largely rural country with an estimated population of over 99 million, of which 81 percent reside in rural areas (World Bank Group 2016). Urbanization in Ethiopia is lower than in most other countries in sub-Saharan Africa, yet levels of urbanization are accelerating rapidly. It is estimated that urban areas in Ethiopia will grow at an annual rate of 3.9 percent between 2015 and 2020, which exceeds the average for Africa as a whole, estimated at 3.1 percent (World Bank 2010).

There has been limited but increasing research on girls' migration in Ethiopia. Contrary to popular assumptions that males are the primary internal migrants in Ethiopia (and elsewhere), 55 percent of internal migrants are female, with young females dominating the population of adolescents in Ethiopia who migrate (Casacchia, Crisci, and Reynaud 2001; Ezra 2001). Studies in Ethiopia's urban slums find that migrant girls are numerous and significantly outnumber migrant boys. One study in low-income/informal settlements of Addis Ababa found that 45 percent of adolescent females were migrants to the area compared to 23 percent of adolescent males (Erulkar et al. 2006). Motivations for migration differed between girls and boys. In a large study in seven regions of Ethiopia, among urban migrant adolescents, boys' main reasons for migration were schooling (43 percent), paid work (35 percent), and accompanying family moves (25 percent). Girls' migration was motivated by schooling (35 percent), paid work (27 percent), accompanying family moves (19 percent), and moving with a spouse (12 percent) (Erulkar et al. 2010). Girls also described moving to escape early marriage, which is probably associated with the lower proportion of female migrants living with parents and family members compared to male migrants (Erulkar et al. 2006). At the same, there is little information on forces driving girls' migration and whether persuasion, coercion, or false promises contribute to decisions to migrate.

Internal migration flow in Ethiopia is generally from low HIV-prevalence rural areas to high prevalence urban areas; HIV prevalence is estimated to be 4.2 percent in urban areas of Ethiopia compared to 0.6 percent in rural areas (FHAPCO 2014). Disadvantaged rural girls with few skills and limited awareness are easily motivated to move with the promise of a better life, but may end up with few livelihood options in urban areas, especially when competing with a better-educated urban labor force. Generally, the low levels of education that girls receive in rural areas puts them at a disadvantage when they reach urban areas where the population is better educated. Newly arriving migrant girls from rural areas frequently have only child domestic work available to them, or other low-status forms of work (van Blerk 2008; de Regt 2016). Child domestic workers are particularly vulnerable to abuse and exploitation, with work involving long hours and little or no pay (Gebre et al. 2012; de Regt 2016). One study in low-income areas of Addis Ababa found that child domestic workers reported an average of 64 hours of work per week for an average pay of US\$6 per month (Erulkar and Mekbib 2007). These exploitative conditions, coupled with peer encouragement, often compel girls to transition into high-risk occupations, including sex work (Gebre et al. 2012). One study of commercial sex workers in five Ethiopian towns found that 42 percent of commercial sex workers were former domestic workers, partly supporting the claim that domestic work is a feeder profession for sex work (Girma and Erulkar 2009). At the same time, there is very little research on work-role histories of girls and the nature of the transition from one form of work to another. As well, data is limited on how and why young women enter into commercial sex work/commercial sexual exploitation and what the motivation is for nondomestic workers to initiate such work. Such information is critical for HIV-prevention programs targeting out-of-school girls.

Like many countries in sub-Saharan Africa, the HIV infection rates among adolescent females and young women in Ethiopia outweigh those of adolescent males and young men. For example, rates of HIV among young women aged 20 to 24 are six times those of males in the same age group (0.6 percent among females; 0.1 percent among males) (FHAPCO 2014). There is emerging but limited data suggesting that migrant girls may be at increased risk for HIV infection, over and above their native urban counterparts. Based on the 2005 Ethiopia 
TABLE 1: Percent of young urban females who are HIVpositive, by migration status (EDHS 2005)

\begin{tabular}{|c|c|c|c|}
\hline Age group & $\begin{array}{c}\text { Native } \\
(n=659)\end{array}$ & $\begin{array}{c}\text { Migrant } \\
(n=941)\end{array}$ & $\begin{array}{c}\% \\
\text { difference }\end{array}$ \\
\hline 15 to 19 & 1.5 & 2.6 & $73 \%$ \\
\hline 20 to 24 & 3.8 & 6.6 & $74 \%$ \\
\hline 25 to 29 & 8.3 & 12.4 & $33 \%$ \\
\hline
\end{tabular}

Source: Population Council tabulations of 2005 EDHS.

Demographic and Health Survey (EDHS), ${ }^{1}$ female urban migrants were more likely to be HIV-positive than native urban females (Table 1). The discrepancy was particularly apparent among girls in their adolescent and young adult years; migrant girls 15 to 24 have 74 percent greater rates of HIV compared to their native counterparts. However, to our knowledge, there is no research in Ethiopia exploring why migrant girls may experience excess levels of HIV infection and what conditions or experiences may elevate their risk over and above urban girls who are native to the area. In addition, while globally, and in Ethiopia, rates of HIV among females exceeds that of males, little is known about what makes females-particularly adolescent girlsat much higher risk of HIV than males.

This study is an in-depth examination of the experience of out-of-school adolescent girls in Ethiopia. The study focuses on girls who migrate, which is an increasingly common experience among out-of-school girls in Ethiopia. We explore patterns of migration, transitions into different work roles, and situations that may put out-of-school migrant girls at increased risk of HIV infection or be protective and beneficial to girls. Specifically, we explore the transition from domestic work to sex work, which appears to be a common trajectory among adolescent girls (de Regt 2016). We also explore the role of brokers in girls' transitions and livelihoods, an important linkage to livelihoods, and sources of risk and protection in urban settings. Indications of trafficking in the course of migration are highlighted.

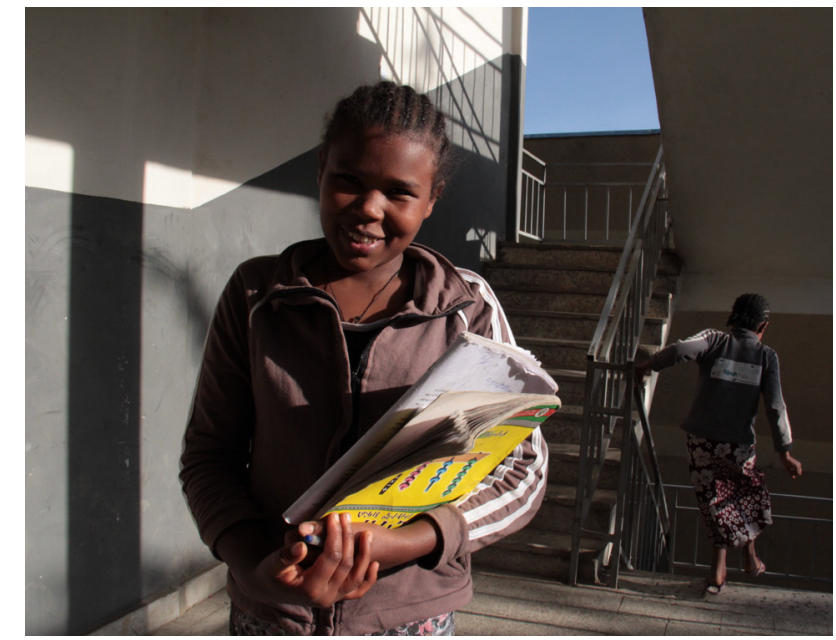

\footnotetext{
1. Migration information was not available in the 2011 EDHS.
} 


\section{Research Design}

This is a study of out-of-school Ethiopian girls, focusing on migration and the transition to different work roles that may increase risk of HIV or prove to be protective and enabling. The study included both qualitative and quantitative phases. An initial large-scale qualitative study was undertaken to frame the issues for the quantitative study and give us a more complete picture of the experience of out-of-school girls' migration and transition between states of risk and protection. Following this, a quantitative survey was undertaken among migrant out-of-school girls, rural girls, and parents, and a special sample of commercial sex workers, bar/café workers, and brokers who channel girls into different forms of work.

\section{Study locations}

The study took place in six regions of Ethiopia: Addis Ababa, Amhara, Dire Dawe, Harar, Oromia, and Tigray. The qualitative study was undertaken in more sites than the quantitative, partly due to security concerns and limitations on travel at the time of the quantitative study. Table 2 shows the urban and rural sites for the qualitative and quantitative data collection.

\section{Respondents and sampling methods}

Multiple categories of out-of-school girls and young women were interviewed, as well as people who have an impact upon their decision to migrate and the migration experience itself: parents, brokers, and other adults who facilitate girls' migration. Table 3 shows the categories of respondents for each phase of the research as well as the strategy used for selecting them. Across respondent categories, all girls were out of school at the time of the survey. The urban respondents were migrants to the area and involved in work roles common to migrating girls.

Where respondents could be sampled through household listings, this was the preferred method of selection. Thus we sampled domestic workers and other out-of-school migrant girls through this method. In each of the study cities, we identified neighborhoods where migrant girls and domestic workers were known to live, mainly low-income areas. We conducted a systematic listing of all households and other structures in the area, such as back rooms of restaurants or establishments where girls may
TABLE 2: Study sites by phase of data collection

\begin{tabular}{|c|c|c|}
\hline & Urban sites & Rural sites \\
\hline Qualitative & $\begin{array}{l}\text { Adama } \\
\text { Addis Ababa } \\
\text { Dessie } \\
\text { Dire Dawe } \\
\text { Metema } \\
\text { Gondar } \\
\text { Harar } \\
\text { Mekelle and } \\
\text { Shashamene }\end{array}$ & $\begin{array}{l}\text { Janimora woreda, } \\
\text { North Gondar zone } \\
\text { Lay Gayint woreda, } \\
\text { South Gondar zone } \\
\text { Raya Azebo wore- } \\
\text { da, Debubawi zone } \\
\text { Huletedere woreda, } \\
\text { South Wollo zone } \\
\text { Hossana Zuria } \\
\text { woreda, Kembatta } \\
\text { zone } \\
\text { Gasara woreda, } \\
\text { Bale zone } \\
\text { Merti woreda, Arsi } \\
\text { zone } \\
\text { Tenbaro woreda, } \\
\text { Hadia zone }\end{array}$ \\
\hline Quantitative & $\begin{array}{l}\text { Adama } \\
\text { Addis Ababa } \\
\text { Dessie } \\
\text { Dire Dawe } \\
\text { Harar } \\
\text { Mekelle } \\
\text { Shashamene }\end{array}$ & $\begin{array}{l}\text { Raya Azebo wore- } \\
\text { da, Debubawi zone } \\
\text { Huletedere woreda, } \\
\text { South Wollo zone } \\
\text { Lodi Hetosa wore- } \\
\text { da, Arsi zone }\end{array}$ \\
\hline
\end{tabular}

spend the night. Interviewers went house-to-house to list members of the household or structure in order to identify girls who were eligible for the study. The same neighborhoods were visited during the qualitative and quantitative study, however a greater number of households and structures were listed during the quantitative study, because of the larger number of respondents sampled in the survey. Following the listing, domestic workers and other migrants were sampled for the qualitative study in a purposeful manner, in order to interview a range of girls from different backgrounds and circumstances. For the quantitative survey, eligible girls were sampled randomly, using the random number generator available in SPSS.

Relatively more hidden and stigmatized populations were sampled through purposeful sampling, visiting places where targeted respondents were known to congregate, 
TABLE 3: Categories of respondents, selection criteria, and method of recruitment, by study arm

\begin{tabular}{|c|c|c|c|}
\hline Category of respondent & Criteria & Qualitative study & Quantitative study \\
\hline Domestic workers & $\begin{array}{l}\text { Female aged } 15 \text { to } 24 \\
\text { working as domestic worker } \\
\text { outside her immediate } \\
\text { family, who migrated before } \\
\text { age } 18 \text { and dropped out of } \\
\text { school before age } 16 .\end{array}$ & $\begin{array}{l}\text { Household listing in urban } \\
\text { locations where child do- } \\
\text { mestic workers are numer- } \\
\text { ous. }\end{array}$ & $\begin{array}{l}\text { Included in selection of } \\
\text { female urban migrants. }\end{array}$ \\
\hline Female urban migrants & $\begin{array}{l}\text { Female aged } 18 \text { to } 24 \text { who } \\
\text { migrated before age } 18 \\
\text { and dropped out of school } \\
\text { before age } 16 .\end{array}$ & $\begin{array}{l}\text { Household listing in urban } \\
\text { areas. }\end{array}$ & $\begin{array}{l}\text { Household listing in urban } \\
\text { areas. }\end{array}$ \\
\hline $\begin{array}{l}\text { Commercial sex workers } \\
\text { (CSWs) }\end{array}$ & $\begin{array}{l}\text { Female aged } 18 \text { to } 24 \text { who } \\
\text { works in commercial sex } \\
\text { work. }\end{array}$ & $\begin{array}{l}\text { Purposeful sampling in ar- } \\
\text { eas where CSWs are found. }\end{array}$ & $\begin{array}{l}\text { Purposeful sampling in ar- } \\
\text { eas where CSWs are found. }\end{array}$ \\
\hline $\begin{array}{l}\text { Brokers and other adults } \\
\text { involved in migration }\end{array}$ & $\begin{array}{l}\text { Licensed or unlicensed } \\
\text { brokers who place girls into } \\
\text { different forms of work, and } \\
\text { other adults who reported } \\
\text { assisting girls' migration. }\end{array}$ & $\begin{array}{l}\text { Purposeful sampling in } \\
\text { areas where brokers are } \\
\text { found. }\end{array}$ & $\begin{array}{l}\text { Purposeful sampling in } \\
\text { areas where brokers are } \\
\text { found. }\end{array}$ \\
\hline Bar/café workers & $\begin{array}{l}\text { Girls aged } 18 \text { to } 24 \text { who } \\
\text { migrated before age } 18 \text {, } \\
\text { dropped out of school be- } \\
\text { fore age } 16, \text { and who work } \\
\text { in bars or cafés. }\end{array}$ & $\begin{array}{l}\text { Included in selection of } \\
\text { female urban migrants. }\end{array}$ & $\begin{array}{l}\text { Purposeful sampling in ar- } \\
\text { eas where bar/café workers } \\
\text { are found. }\end{array}$ \\
\hline Rural girls & $\begin{array}{l}\text { Rural girls aged } 15 \text { to } 17 \\
\text { who live with parent(s) and } \\
\text { are out of school. }\end{array}$ & & $\begin{array}{l}\text { Household listings in rural } \\
\text { areas. }\end{array}$ \\
\hline Rural parents & $\begin{array}{l}\text { Rural parents who have } \\
\text { daughters aged } 12 \text { to } 17 .\end{array}$ & & $\begin{array}{l}\text { Household listings in rural } \\
\text { areas. }\end{array}$ \\
\hline
\end{tabular}

and approaching potential respondents for interviews. Importantly, despite early skepticism that brokers would not agree to be interviewed, we were able to reach a considerable number of brokers in the context of this study.

\section{Training and data collection}

Interviewers for the qualitative study were recruited mainly in Addis Ababa, with preference given to those who had conducted open-ended interviews previously and had language capabilities required in the different study sites. Interviewers for the quantitative survey were recruited from the study regions, to ensure that they possessed relevant language capabilities and an understanding of the local culture and community. In both phases of the study, only female interviewers interviewed female respondents and male interviewers interviewed male respondents. As such, we recruited a larger number of female interviewers given that the majority of study respondents were female. In all, 22 interviewers and supervisors were recruited and trained for the qualitative study. Because of the large sample size for the survey, a much larger number of survey interviewers and supervisors were recruited and trained: 342 in urban areas and 140 in rural areas.

Interviewers were trained for one day prior to the household listing for both phases of the research. Qualitative interviewers were trained for six days by a PhD anthropologist and other Population Council staff, and then received an additional four days of refresher training midway through data collection. The training included in-depth review of the study objectives and the suggested discussion guides, as well as mock interviews and participant review and critique of interview styles. The survey interviewers were trained for seven days. Interviewers reviewed the questionnaire item by item, reviewed ethical procedures including informed consent and actions taken in the case of adverse events, and engaged in practice interviews in pairs, ensuring understanding and adherence to skip patterns and general questionnaire administration. 
In the context of the qualitative study, respondents were interviewed over one to three visits paid by the interviewer. Our experience in interviewing marginalized or reticent populations is that multiple visits frequently ease the misgivings of the respondent; they often become more candid as the number of interview visits increases. All interviews were tape recorded, translated into English, and transcribed into Word documents. Qualitative data were analyzed for emergent themes and patterns in the data. Two research assistants analyzed themes and patterns independently and then came together to discuss what each had identified. Common themes and patterns were drafted in a report of findings from this phase of the study.

For the quantitative study, structured questionnaires for girls (domestic workers, urban migrants, rural girls, bar/ café workers, and commercial sex workers), parents, and brokers were developed, pretested, and translated into local languages. Questionnaires for girls elicited information on demographic and socioeconomic characteristics, education and schooling, families and social networks, migration, livelihoods, brokers, mental health, marriage, sexual experience, HIV knowledge and behavior, family planning and pregnancy, and utilization of services. Questions for brokers and parents were abbreviated instruments that focused on brokers' support to girls, and parents' views on migration.

All data were transported from the field to Population Council offices in Addis Ababa and entered by trained data-entry clerks. Data were converted to SPSS for analysis. We investigated the characteristics and experiences of different categories of out-of-school girls, including their levels and sources of risk and protective factors. Because a large proportion of urban migrants were in domestic work, we separated out girls in domestic work as a different category. For the purposes of analysis, we compared different categories of girls across a range of issues and experiences.

Both the qualitative and quantitative study received ethical approval from the Population Council's Institutional Review Board (IRB) and the National Research Ethics Committee in Ethiopia.

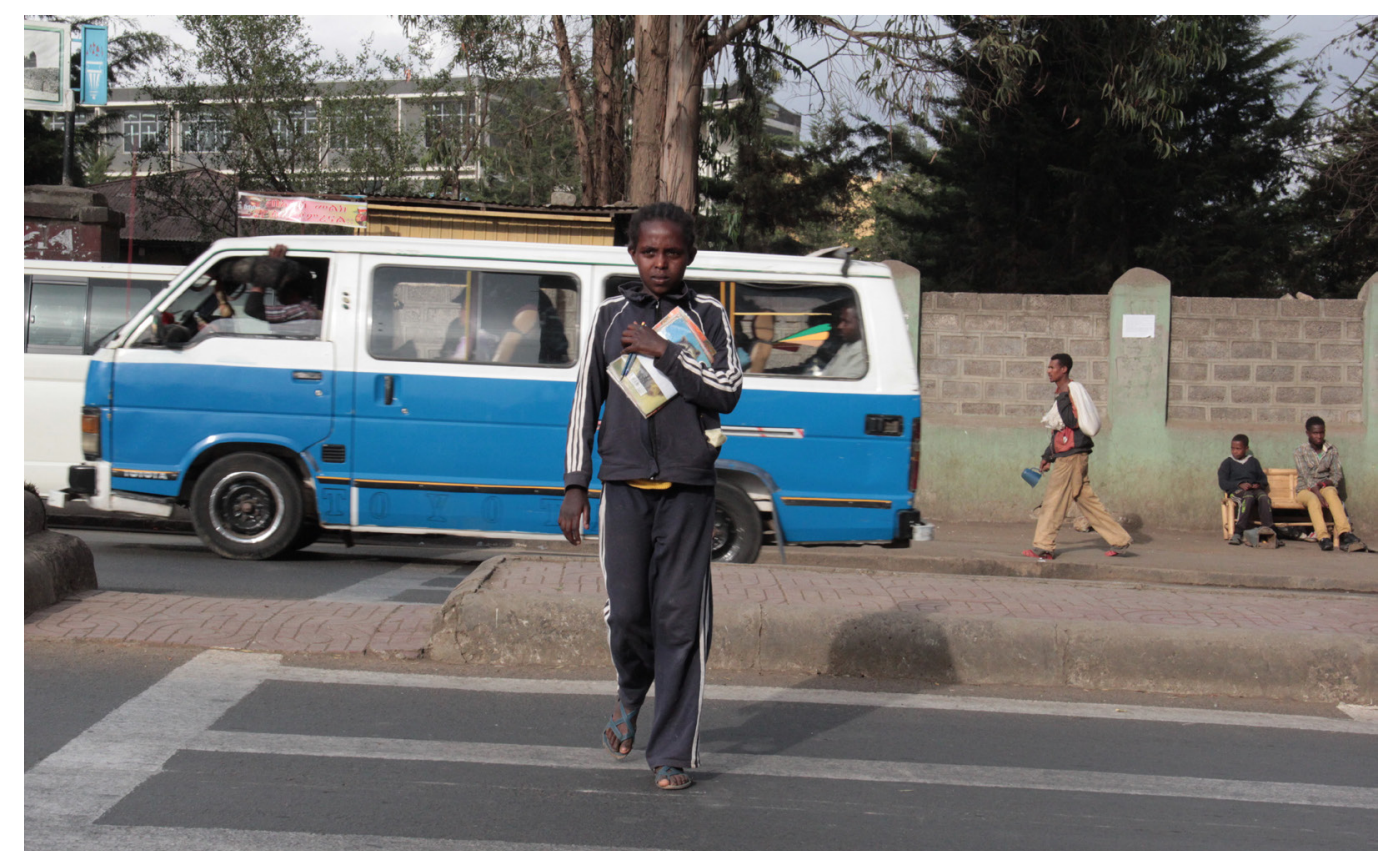




\section{Sample Characteristics}

In all, 143 qualitative respondents were interviewed. As most respondents in the qualitative study were interviewed over several rounds of discussion, 330 separate interview sessions were conducted. In this phase of the study, we interviewed 47 domestic workers, 20 urban migrants in other forms of work, 37 commercial workers, and 39 brokers or other adults who facilitate migration.

Table 4 shows the characteristics of the sample of girls from the quantitative survey. Four of the five categories of female respondents were urban migrants who were either in domestic work, commercial sex work, bar/café work, or in other situations. Overall, 4,540 out-of-school female migrants were interviewed across the four categories. As well, 732 rural girls-17 percent were previous migrantswere also interviewed.

Urban respondents were an average of 19 years of age among domestic workers, and 20 or 21 years among migrants in other categories. All respondents were out of school at the time of the survey. Overall, domestic workers had the lowest mean years of education (3.7 years), followed by commercial sex workers who had an average of 4.1 years of education. A large proportion of

TABLE 4: Sample characteristics by category of respondent

\begin{tabular}{|l|c|c|c|c|c|}
\hline & \multicolumn{4}{|c|}{ URBAN MIGRANTS } & RURAL \\
\hline & $\begin{array}{c}\text { Domestic } \\
\text { workers } \\
(n=1,094)\end{array}$ & $\begin{array}{c}\text { Other urban } \\
\text { migrants } \\
(n=2,289)\end{array}$ & $\begin{array}{c}\text { Commercial } \\
\text { sex workers } \\
(n=796)\end{array}$ & $\begin{array}{c}\text { Bar/café work- } \\
\text { ers ( } n=361)\end{array}$ & $\begin{array}{c}\text { Rural girls } \\
(n=732)\end{array}$ \\
\hline Age (mean) & 19.2 & 20.5 & 20.8 & 20.0 & 16.0 \\
\hline Religion & 59.4 & 45.3 & 67.2 & 66.8 & 35.6 \\
$\quad$ Orthodox & 31.2 & 44.3 & 22.2 & 21.5 & 63.9 \\
$\quad$ Muslim & 9.4 & 10.4 & 10.6 & 11.7 & 0.5 \\
$\quad$ Other & 3.7 & 4.3 & 4.1 & 5.4 & 4.3 \\
\hline Years of education (mean) & & & & & \\
\hline Educational attainment & 26.4 & 22.5 & 28.8 & 13.0 & 20.5 \\
$\quad$ None & 32.0 & 27.2 & 19.2 & 19.4 & 30.7 \\
1 to 4 years & 39.2 & 44.4 & 48.5 & 59.5 & 44.5 \\
5 to 8 years & 2.5 & 6.0 & 3.5 & 7.8 & 4.2 \\
9+ years & & & & & \\
\hline Number of living parents & 4.8 & 8.5 & 17.3 & 7.6 & 2.5 \\
$\quad$ None & 24.7 & 28.5 & 31.1 & 25.5 & 19.5 \\
1 & 70.6 & 63.0 & 51.6 & 67.2 & 78.1 \\
\hline 2 & & & & & \\
\hline Asset ownership & 3.2 & 15.9 & 15.5 & 11.9 & 1.1 \\
Owns a radio & 52.7 & 67.2 & 70.5 & 75.9 & 23.4 \\
Owns mobile phone & 5.3 & 22.4 & 23.2 & 18.0 & 3.7 \\
Owns bed & 42.0 & 66.2 & 55.7 & 55.7 & 37.3 \\
Owns a blanket & 23.4 & 54.2 & 51.2 & 50.4 & 12.6 \\
\hline Percent with 2+ assets (above) & & & & & \\
\hline Marital status & 80.8 & 29.4 & 69.6 & 71.7 & 83.4 \\
Never married & 10.1 & 64.4 & 5.5 & 18.5 & 12.5 \\
Currently married & 9.1 & 6.2 & 24.8 & 9.7 & 4.2 \\
\hline Formerly married & & & & \\
\hline
\end{tabular}


girls in both of these groups had never been to school at all: 26 percent of domestic workers and 29 percent of sex workers. Few girls had 9 or more years of education, ranging from 8 percent of bar/café workers, to 6 percent of other migrants, to only 3 percent of domestic workers. Compared to the other categories of girls interviewed, a considerable percentage of commercial sex workers were double orphans (17 percent) and were formerly married (25 percent).

We asked respondents about personal ownership of four basic assets: radio, mobile phone, bed, and blanket. Mobile phones were the most commonly owned asset among 76 percent of bar/café workers, 71 percent of commercial sex workers, and 67 percent of other urban migrants. Among urban girls, the lowest proportion with a mobile phone were domestic workers (53 percent), while only 23 percent of rural girls had a mobile phone. Although radio represents a major source of information, few girls owned one: 16 percent of other migrants and commercial sex workers, 12 percent of bar/café workers, 3 percent of domestic workers, and 1 percent of rural girls. 


\section{Social Networks and Safety Nets}

Table 5 shows out-of-school girls' possession of identity cards, as well as friendship networks and sources of support in their communities. Few respondents had a birth certificate, ranging from $<1$ percent of rural girls to 3 percent of bar/café workers. Comparatively, a larger percentage had kebele identity (ID) cards. The category of respondent holding the largest percent of kebele IDs was café/bar workers (50 percent), followed by other categories of urban migrants (48 percent). The respondent categories least likely to have a kebele ID were rural girls (24 percent) and domestic workers (38 percent). A moderate percentage of girls reported having a bank account, especially bar/café workers (44 percent), commercial sex workers (35 percent), and domestic workers (26 percent). Very few rural girls had bank accounts (3 percent).

Rural girls were the most likely to have larger numbers of friends, with 29 percent reporting that they have two or more close friends, compared to less than 25 percent of the other categories of girls. Domestic workers were the most likely to report having no friends whatsoever: 58 percent.

Likewise, rural girls reported the highest levels of community support, compared to their counterparts in urban areas. Among rural girls, 73 percent said that they had an

TABLE 5: Identity cards, friendship networks, and community support, by category of respondent

\begin{tabular}{|c|c|c|c|c|c|}
\hline & \multicolumn{4}{|c|}{ URBAN MIGRANTS } & \multirow{2}{*}{$\begin{array}{c}\text { RURAL } \\
\text { Rural girls } \\
(n=732)\end{array}$} \\
\hline & $\begin{array}{c}\text { Domestic } \\
\text { workers } \\
(n=1,094)\end{array}$ & $\begin{array}{l}\text { Other urban } \\
\text { migrants } \\
(n=2,289)\end{array}$ & $\begin{array}{l}\text { Commercial sex } \\
\text { workers }(n=796)\end{array}$ & $\begin{array}{l}\text { Bar/café work- } \\
\text { ers }(n=361)\end{array}$ & \\
\hline \multicolumn{6}{|l|}{ IDENTITY CARDS } \\
\hline Has a kebele ID & 38.0 & 47.8 & 41.7 & 50.1 & 23.6 \\
\hline Has a birth certificate & 1.6 & 2.9 & 2.3 & 3.0 & 0.8 \\
\hline Has a bank account & 25.9 & 24.3 & 34.7 & 44.3 & 2.7 \\
\hline \multicolumn{6}{|l|}{ SOCIAL NETWORKS } \\
\hline \multicolumn{6}{|l|}{$\begin{array}{l}\text { Number of good female } \\
\text { friends }\end{array}$} \\
\hline None & 57.9 & 47.3 & 44.7 & 45.4 & 42.8 \\
\hline 1 & 21.1 & 30.9 & 31.2 & 31.0 & 28.6 \\
\hline 2 or more & 21.0 & 21.8 & 24.1 & 23.5 & 28.7 \\
\hline \multicolumn{6}{|c|}{ SOCIAL SUPPORT (percent agreeing with the statement) } \\
\hline $\begin{array}{l}\text { There is someone in the } \\
\text { community you can bor- } \\
\text { row money from. }\end{array}$ & 36.8 & 50.9 & 32.6 & 45.0 & 60.4 \\
\hline $\begin{array}{l}\text { There is someone in the } \\
\text { community you could stay } \\
\text { with if you needed shelter. }\end{array}$ & 42.2 & 56.8 & 28.2 & 48.6 & 72.5 \\
\hline $\begin{array}{l}\text { There is someone in the } \\
\text { community you could } \\
\text { confide in about rape. }\end{array}$ & 40.7 & 50.0 & 35.2 & 45.6 & 65.5 \\
\hline $\begin{array}{l}\text { You feel protected by } \\
\text { police/law enforcement in } \\
\text { your community. }\end{array}$ & 65.4 & 74.2 & 81.2 & 76.7 & 68.5 \\
\hline
\end{tabular}


alternative place to stay in their community if they needed it and 66 percent reported that there was a trusted confidante whom they could confide in about a rape experience. Commercial sex workers and domestic workers reported the lowest levels of support on issues such as having someone from whom they can borrow money (33 percent of commercial sex workers and 37 percent of domestic workers) and having an alternative place to stay (28 percent of commercial sex workers and 42 percent of domestic workers). Interestingly, commercial sex workers reported the highest levels of perception of police support and protection (81 percent), with the lowest level reported by domestic workers (65 percent).

Qualitative interviews reflected the social isolation that many migrants feel after migration. Many complained of having no one to turn to for advice or support:

In this world of sex work, every woman worries about herself and her own benefits. No one cares for each other. No one thinks, "If I get sick, who will be there for me?" Everybody saves money for themselves, and if they get sick they just take their money and go to the hospital. Even if you trembled on the ground sick, no one will reach out to you and bring you water.

-Commercial sex worker in Addis Ababa, age 18, migrated at age 14,7 years of education

I have no one. Some people that I know would come to visit me but I have no one to ask me about what I am going through and what my problems are. -Waitress in Addis Ababa, age 18, migrated at age 12, 7 years of education

Respondents were read a series of statements about their relationships with their parent(s) and asked if they agreed or disagreed. Rural parents were read series of similar statements about communication with adolescent daughters (Table 6). Responses reflect parent-child relationships with limited communication and dialogue. Only two-thirds of girls and young women reported that their parents valued schooling and the same proportion wished they could speak with their parents more freely. Only one in five girls (21 percent) reported that their parents had talked to them about HIV and AIDS and one in ten (11 percent) said that their parents had talked to them about sex. When parents were asked if they had talked to their daughters about HIV/AIDS and sex, a greater proportion reported such discussions: 53 percent of parents report- ed talking about HIV/AIDS while 25 percent said that they had talked to their daughters about sex. Only 37 percent of girls felt they could talk to their parents about very personal issues such as rape or violence, while 52 percent of parents reported that such discussions were possible with their daughters. While there were not very large differences between categories of respondents, commercial sex workers reported the most limited communication with their parents. Additionally, they were the least comfortable talking to their parents about the work they do.

Lack of parental support-especially for schooling-was expressed in qualitative interviews:

I was not going to school that much. When we started working in the false banana farm, my mother didn't want me to go to school anymore. She wanted me to help her at the farm. Sometimes, my father asked me to stay home from school even though I wanted to get an education. He even hit me once when I told him I wanted to go to school.... I eventually quit school. -Assistant cook in Adama, age 18, migrated at age 15,6 years of education 
TABLE 6: Parent-child relationships among urban and rural out-of-school girls and rural parents

\begin{tabular}{|l|c|c|}
\hline \multicolumn{1}{|c|}{ Statement (Percentage agreeing with the statement) } & $\begin{array}{c}\text { Out-of-school } \\
\text { girls } \\
\text { (n=5,272) }\end{array}$ & $\begin{array}{c}\text { Parents } \\
\text { (n=668) }\end{array}$ \\
\hline You wish you could (have) talk(ed) to your parents more freely. & 65.0 & - \\
\hline Your parent(s) value(d) education/schooling. & 64.9 & - \\
\hline You feel comfortable talking to your parents about the work you do. & 43.8 & - \\
\hline Your parents understand/understood you and your concerns. & 48.6 & - \\
\hline $\begin{array}{l}\text { You could talk to your parent(s) about personal issues such as rape or violence./ } \\
\text { You could talk to your daughter about very personal issues such as rape or violence. }\end{array}$ & 37.3 & 52.3 \\
\hline $\begin{array}{l}\text { Your parent(s) talked to you about marriage./You have talked to your daughter about } \\
\text { marriage. }\end{array}$ & 32.9 & 50.2 \\
\hline $\begin{array}{l}\text { Your parents talked to you about migrating or moving to other locations./You have } \\
\text { talked to your daughter about migrating or moving to other locations. }\end{array}$ & 31.9 & 45.0 \\
\hline $\begin{array}{l}\text { Your parent(s) talked to you about HIV/AIDS./You have talked to your daughter about } \\
\text { HIV/AIDS. }\end{array}$ & 21.1 & 52.9 \\
\hline Your parent(s) talked to you about sex./You have talked to your daughter about sex. & 10.9 & 24.5 \\
\hline Your parents have talked to you about girls who do sex work. & 5.8 & - \\
\hline
\end{tabular}

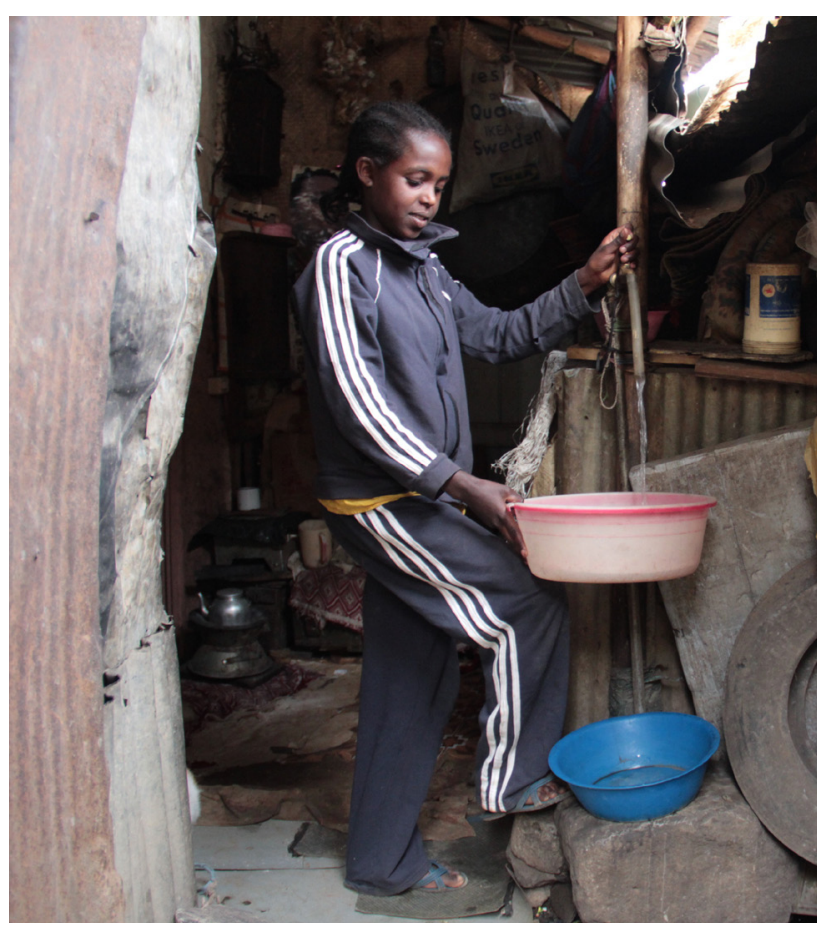




\section{Migration}

\section{Attitudes toward migration}

We compared the attitudes and perceptions of urban migrants and rural girls on various aspects of migration (Table 7). Girls in rural areas were significantly more likely to have positive perceptions of migration compared to girls who had already migrated. For example, 75 percent of rural girls felt that migrating girls were better off than those who stay in rural areas and 77 percent felt that most migrating girls get well-paid professional jobs after their moves. The percent of urban migrants holding the same opinions were 67 and 70 percent, respectively, differences between groups that were statistically significant. Likewise, few rural girls knew of or believed that migrating girls get involved in trading sex for money, whereas a significantly greater proportion of migrant girls were aware of this pattern.

TABLE 7: Attitudes and perceptions about migration among female urban migrants and rural girls, by category of respondent (percent agreeing with the statement)

\begin{tabular}{|c|c|c|c|}
\hline & $\begin{array}{l}\text { Urban migrants } \\
\qquad(n=4,539)\end{array}$ & $\begin{array}{l}\text { Rural residents } \\
\qquad(n=732)\end{array}$ & $\begin{array}{l}\text { Rural parents } \\
\qquad(\mathrm{n}=668)\end{array}$ \\
\hline \multicolumn{4}{|l|}{ Attitudes about migration } \\
\hline $\begin{array}{l}\text { If a 15-year-old girl who is out of school wants to migrate but her } \\
\text { parents don't want her to, she should not migrate. }\end{array}$ & 55.1 & $60.4 * *$ & 71.9 \\
\hline $\begin{array}{l}\text { If a 14-year-old girl is about to be forced into marriage, she } \\
\text { should consider migrating to another place. }\end{array}$ & 48.7 & 49.5 & 31.0 \\
\hline $\begin{array}{l}\text { Girls who migrate are better off than those who stay in rural } \\
\text { areas. }\end{array}$ & 67.1 & $75.4 * * *$ & 65.1 \\
\hline $\begin{array}{l}\text { The majority of girls who migrate get well-paying, professional } \\
\text { jobs in the city. }\end{array}$ & 70.4 & $76.9 * * *$ & 71.1 \\
\hline $\begin{array}{l}\text { Girls who migrate and move back to their rural homes are usually } \\
\text { failures. }\end{array}$ & 54.7 & $61.3 * *$ & 65.0 \\
\hline $\begin{array}{l}\text { You know of migrant girls who got involved in having sex for } \\
\text { money or gifts. }\end{array}$ & 29.3 & $5.2 * * *$ & 17.5 \\
\hline $\begin{array}{l}\text { Many girls who migrate get involved in having sex for money or } \\
\text { gifts. }\end{array}$ & 27.5 & $6.1 * * *$ & 14.4 \\
\hline \multicolumn{4}{|l|}{ Encouragement and support to migrate } \\
\hline $\begin{array}{l}\text { You know of a person in your hometown/neighborhood who } \\
\text { would help you/your daughter migrate to another location if you } \\
\text { wished. }\end{array}$ & 23.4 & 23.0 & 23.1 \\
\hline $\begin{array}{l}\text { You/your daughter(s) have been encouraged to migrate by a } \\
\text { neighbor or friend. }\end{array}$ & 18.4 & 17.6 & 13.3 \\
\hline $\begin{array}{l}\text { You have been encouraged to migrate by one or both of your } \\
\text { parents/guardians./You or your spouse have encouraged your } \\
\text { daughter(s) to migrate. }\end{array}$ & 14.3 & 13.1 & 9.0 \\
\hline $\begin{array}{l}\text { You know of a broker who would help you/your daughter(s) } \\
\text { migrate. }\end{array}$ & 21.7 & $7.7 * * *$ & 20.1 \\
\hline $\begin{array}{l}\text { If you/your daughter(s) wanted to migrate to another location, } \\
\text { you know of someone who would take you/her in. }\end{array}$ & 21.1 & 19.3 & 26.2 \\
\hline
\end{tabular}

Differences between girls' groups significant at $* p<0.05 * * p<0.01 * * * p<0.001$. 


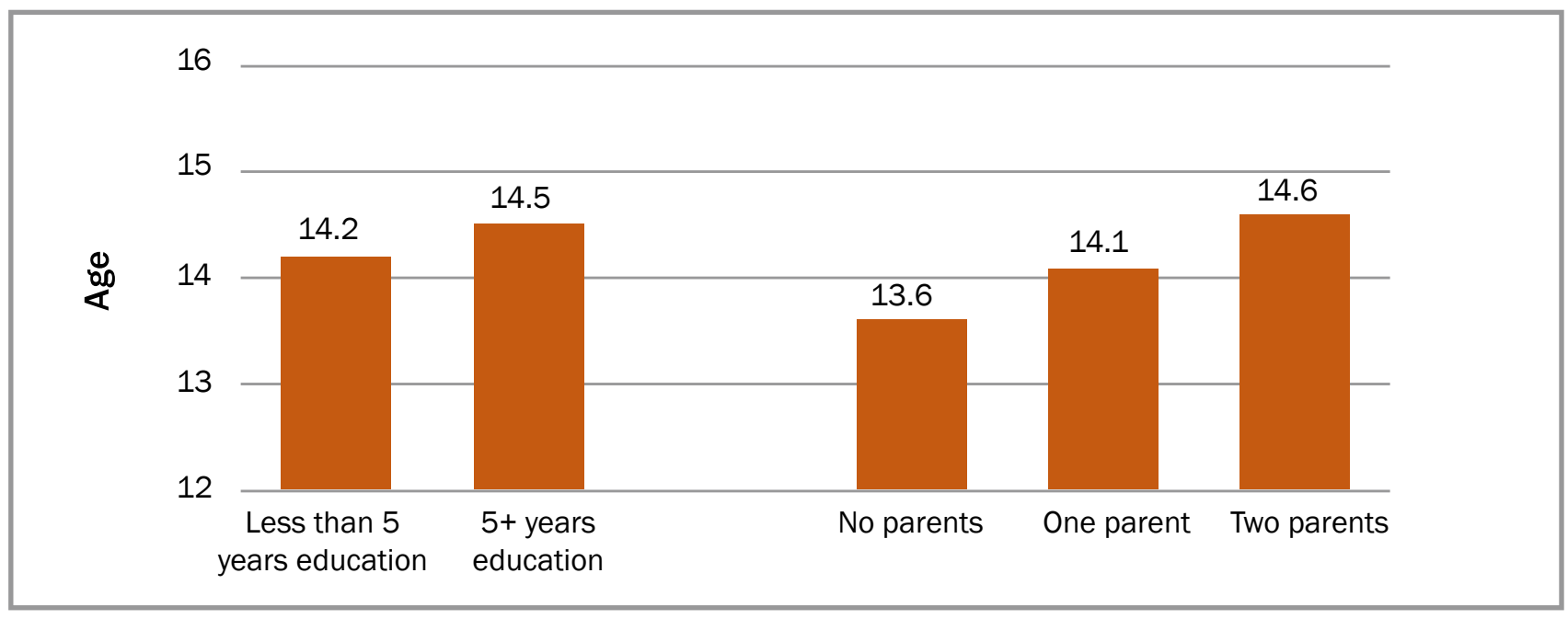

FIGURE 2: Months for migration and months of food scarcity in rural areas

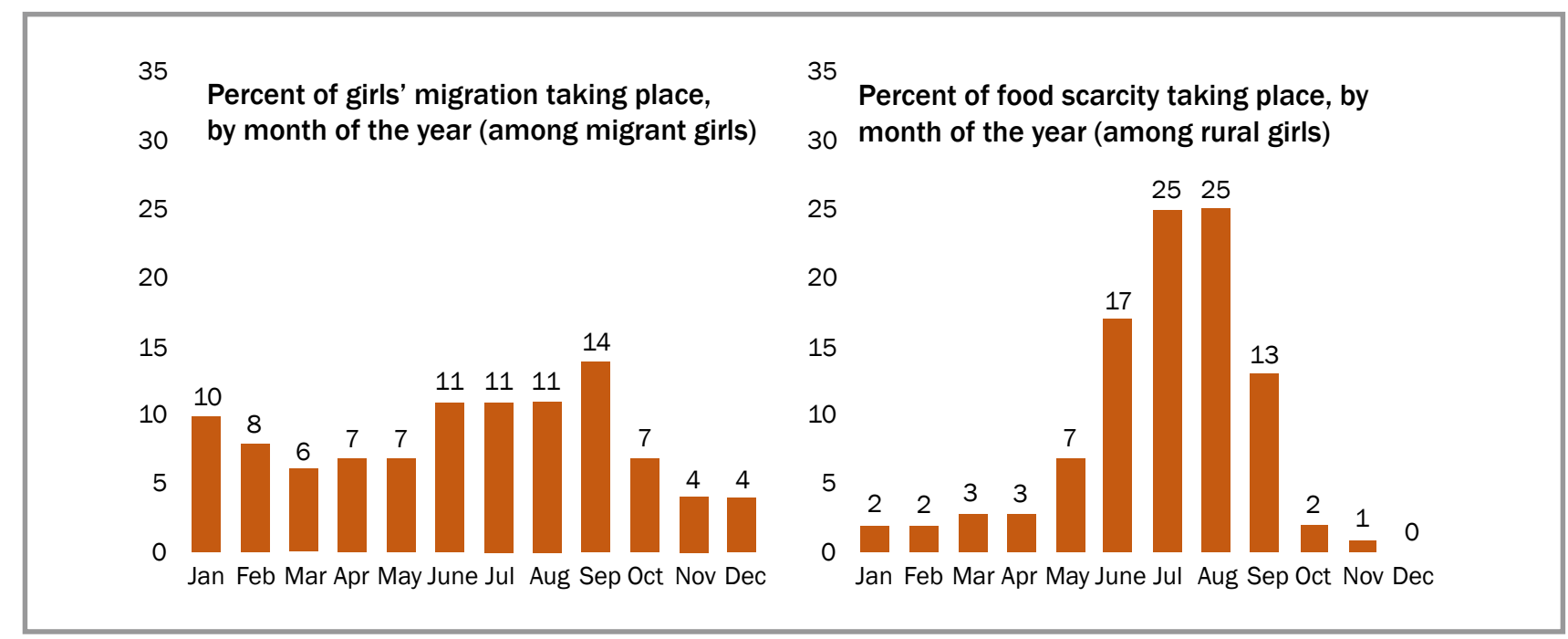

Rural parents were also asked similar questions about attitudes toward migration and encouragement of daughter(s) to migrate. ${ }^{2}$ A higher proportion of rural parents compared to girls believed that girls should not migrate if the parents opposed the migration (72 percent). Likewise, a lower proportion believed that girls whose marriages had been arranged should consider migrating to escape the marriage (31 percent). Rural parents seemed more aware of migrating girls who got involved in sex work (18 percent) compared to girls in rural areas (5 percent). They also seemed more aware of brokers who assist girls in migration (20 percent) compared to girls in rural areas
(8 percent). Compared to girls, fewer parents reported that their daughters had been encouraged to migrate (13 percent) or that they had encouraged their daughters to migrate (9 percent).

\section{Age and timing of migration}

Mean age at first migration was 14.3 years. Girls who were orphaned and those who had fewer years of education were significantly more likely to migrate at younger ages (Figure 1). On average, girls with no parents migrated at the age of 13.6, compared to girls with two parents who migrated an average of one year later, at 14.6 years. ${ }^{3}$

\footnotetext{
2. We did not undertake significance testing comparing parents' responses to girls' responses.

3. Parental survival is recorded at time of survey and not at time of migration.
} 
We collected in-depth information on up to three migration events, including month of migration. We pooled data from the three events and calculated the distribution of months during which girls reported undertaking migration (Figure 2A). Likewise, respondents were asked during what month of the year they experience the most food scarcity (Figure 2B), and focused on responses from rural areas. Months of migration are more evenly distributed throughout the year than are reported months of food scarcity in rural areas. However, the peak months for migration, June through September, also appear to be the peak months for food scarcity in rural areas.

\section{Motivations, encouragement, and accompaniment}

When asked about motivations for the most recent migration, the main reason given was "to find a better life" among 64 percent of migrants, followed by to find work (55 percent) and to live with a spouse/partner (10 percent). Table 8 shows accompaniment, approval, and encouragement for the most recent migration. More than one-third (39 percent) of girls migrated on their own without accompaniment, while 42 percent migrated with a relative, spouse/partner, or sibling. Forty-one percent of respondents said that they were encouraged or persuaded to migrate, with the main encouragement coming from relatives (27 percent), friends (23 percent), parents (17 percent), and siblings (16 percent). About two-thirds (66 percent) of respondents reported that their parents knew about their most recent migration and the majority (79 percent) approved of the migration. One in five migrants (20 percent) believed they would move to another location in the next year, which was a more commonly held view among commercial sex workers than among other categories of respondents.

In qualitative interviews, respondents described migration as a strategy to escape rural poverty, hardship, and a forced early marriage, as well as resulting from poor relationships with parents. In particular, step-parents were a source of much discord at home, which is consistent with other studies of girls' migration in Ethiopia (de Regt 2016).

I never knew my mother because she passed away when I was young. There was only my father and my stepmother. I used to get into fights with my stepmoth er. Although she never beat me, she used to refuse to talk to me for days and I didn't understand why. -Domestic worker in Addis Ababa, age 18, migrated at 15,4 years of education
TABLE 8: Accompaniment, encouragement, and approval during most recent migration $(n=4,634)$

\begin{tabular}{|c|c|}
\hline $\begin{array}{l}\text { Accompaniment during most recent } \\
\text { migration }^{1}\end{array}$ & Percent \\
\hline No one/alone & 39.4 \\
\hline Other relative & 20.3 \\
\hline Spouse/partner & 11.5 \\
\hline Sibling & 10.0 \\
\hline Friend & 8.3 \\
\hline Parent & 5.3 \\
\hline Acquaintance/neighbor & 4.6 \\
\hline Employer/broker & 2.5 \\
\hline $\begin{array}{l}\text { Percent who were encouraged or } \\
\text { persuaded to migrate }\end{array}$ & 40.5 \\
\hline \multicolumn{2}{|l|}{$\begin{array}{l}\text { Among those who were encouraged, } \\
\text { source of encouragement }\end{array}$} \\
\hline Other relative & 27.0 \\
\hline Friend & 22.5 \\
\hline Parent & 17.4 \\
\hline Sibling & 16.1 \\
\hline Spouse/partner & 14.3 \\
\hline Acquaintance/neighbor & 6.8 \\
\hline Employer/broker & 3.4 \\
\hline $\begin{array}{l}\text { Percent whose parent(s) knew about } \\
\text { migration }\end{array}$ & 65.9 \\
\hline $\begin{array}{l}\text { Among parents who knew about } \\
\text { migration, percent that approved }\end{array}$ & 78.8 \\
\hline
\end{tabular}

${ }^{1}$ Responses may sum to over 100 percent, as more than one response was allowed.

One of the reasons that girls flood to this city is because of early marriage. In rural parts of Ethiopia, they marry girls off while they are still children. Girls hate it. In addition, there are a lot of people who live in poverty.... The girls are trying to help their families by migrating. It is because of these two reasons that the girls come. -Unlicensed broker in Metema, age 32, 9 years of education

A minority of parents encouraged girls' migration and only two-thirds knew about the migration of their daughters. While surveyed girls reported that their parents approved of the migration, many parents interviewed in the qualitative study expressed disapproval and worry about girls' migration. Chief among parents' concerns are worries about HIV infection.

It is better when males go [to the city] rather than females. Females can become infected with diseases. Even if they work, they can be robbed. Females are weak.... After they [girls] go to the city and start living 
there, they become infected with the disease [HIV] and they return. A man who married one of them died...she is still alive. Once it was known she has the disease, no one goes anywhere near her house.

-Father, age 45, farmer, 1 migrant daughter, 3 years of education

Families feel angry [when their daughters come to visit]. They become suspicious of the girls' health even if they dress neatly and look OK physically. It takes time to be sure about their health and life. -Father, age 44, farmer, 2 migrant daughters, no education

For many migrant girls, the decision to move is made on the spur of the moment, with very little planning involved. Girls who migrated abruptly often did so alone or with an equally young and inexperienced friend or relative.

I took 100 birr from my mother and I ran away.... My cousin and I just talked about it, agreed it would be better for us in the city. Addis was an important place to us so we told our parents that we were going to school and left home early in the morning and ran away. -Domestic worker, Addis Ababa, age 18, migrated at age 14,4 years of education

I was told to take firewood and grass to the market to sell and provide income for the family. I went to chop firewood and I cut my leg with the axe. I was fed up and I decided that I would rather be hired as a domestic worker than carry firewood.... I made my decision on that day and left. -Returning migrant, age 19, migrated at age 16, 1 year of education

This lack of planning arguably puts girls at increased risk during their journey and upon arrival in the city, as they often do not have plans for where they will stay or how they will settle.

There was this girl who came from the southern region. She ran away from her family and had nowhere to go. She was crying right at the taxi station here. She had no luggage whatsoever and knew nothing about the city. We asked what was wrong and this lady came asking where this girl is from and took her saying that she would take care of a baby in her house. -Broker in Addis Ababa, age 32, 8 years of education
In fact, it was really bad. It was winter and it was raining. While it was raining, we used to spend the night [on the street] standing and we used to sleep during the daytime.... Even if we wanted to sleep at night, we wore plastic and slept on a sack. In addition, there were boys and they used to come drunk and it was horrible.... You know like when they see new girls, they just see you differently. They just want you to sleep with them and do bad things. -Commercial sex worker, Addis Ababa, age 18, migrated at age 14,

7 years education

\section{Migration histories}

We asked urban migrants about their migration histories, starting with place of birth/origin and then detailing each location where they lived for six months or more. Among migrants, the majority had only lived in one location other than their rural birthplace (70 percent). A much smaller percentage had lived in two locations (20 percent), three locations ( 7 percent), or four or more locations (3 percent). Few (roughly 11 percent) migrated or had stopovers in smaller regional towns. This suggests that step migration may not be as common as is assumed in Ethiopia,

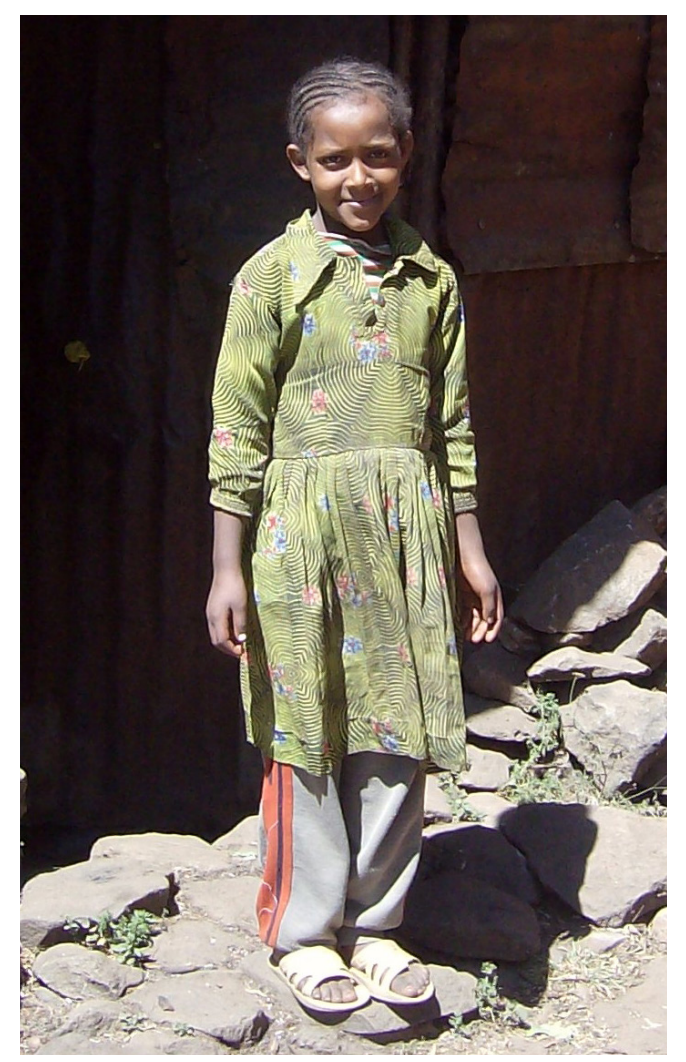


TABLE 9: Patterns of migration and status of migrants, by migration history

\begin{tabular}{|c|c|c|c|c|}
\hline & $\begin{array}{l}\text { Birthplace } \\
(n=4,540)\end{array}$ & $\begin{array}{l}\text { First point of } \\
\text { migration } \\
(n=4,465)\end{array}$ & $\begin{array}{l}\text { Second point of } \\
\text { migration } \\
(n=1,401)\end{array}$ & $\begin{array}{l}\text { Third point of } \\
\text { migration }(n=457)\end{array}$ \\
\hline \multicolumn{5}{|l|}{ Age of arrival } \\
\hline Below age 10 & - & 8.2 & 2.2 & 2.0 \\
\hline Age 10 to 14 & - & 30.2 & 15.1 & 8.3 \\
\hline Age 15 to 19 & - & 60.8 & 70.4 & 61.6 \\
\hline Age 20+ & - & 0.8 & 12.3 & 28.2 \\
\hline \multicolumn{5}{|l|}{ Type of place of residence } \\
\hline Rural & 74.3 & 2.1 & 5.3 & 2.4 \\
\hline Small town & 17.9 & 10.9 & 10.7 & 10.5 \\
\hline Big city & 7.8 & 87.0 & 83.9 & 87.1 \\
\hline \multicolumn{5}{|l|}{ Household head } \\
\hline Parent(s) & 88.2 & 4.7 & 7.1 & 8.4 \\
\hline Employer & 0.5 & 34.0 & 35.9 & 27.5 \\
\hline Self & 1.1 & 21.9 & 25.5 & 31.9 \\
\hline Other & 10.2 & 35.4 & 31.5 & 32.2 \\
\hline Attended school (yes) & 63.0 & 13.0 & 6.9 & 4.6 \\
\hline Worked for pay (yes) & 3.6 & 70.5 & 73.4 & 72.6 \\
\hline \multicolumn{5}{|l|}{ Type of work ${ }^{1}$} \\
\hline Domestic work & 59.9 & 66.9 & 53.8 & 43.1 \\
\hline Waitress/service industry & 11.9 & 12.9 & 18.1 & 18.6 \\
\hline Commercial sex work & 5.9 & 10.9 & 16.3 & 21.3 \\
\hline Other & 23.3 & 9.3 & 11.8 & 17.1 \\
\hline Contact with a broker (yes) & 1.3 & 21.5 & 27.2 & 26.0 \\
\hline Overall experience was "good" & 75.9 & 83.3 & 81.1 & 81.6 \\
\hline
\end{tabular}

${ }^{1}$ Among those working for pay.

which is consistent with other studies of migration (World Bank 2010; Temin et al. 2013). Otherwise, the young age of our respondents may bias our results toward fewer post-migration residences, with a larger number of moves recorded in later years. Seventy-four percent of migrants originated in rural areas, with the vast majority (over 80 percent) migrating directly to big cities.

Migration marked abrupt changes in schooling and work status as well as living arrangements. While the majority of girls were attending school before migration (63 percent), only 13 percent of girls were attending when they moved to their first post-migration location, and 7 percent attended after their second move. Conversely, paid work increased dramatically. While only 4 percent of girls worked for pay in their birthplace, over 70 percent of girls worked for pay after migration. However, patterns of work evolved with successive moves. After migration, the vast majority of migrants entered domestic work (67 percent of those working for pay). After successive moves, the percent of girls involved in domestic work decreased (54 percent of girls after their second move; 43 percent of girls after their third move). Conversely, engagement in commercial sex work increased with successive moves (11 percent of girls in their first move; 16 percent in their second move; 21 percent in their third move). Likewise, the likelihood that girls had contact with a broker increased with the increased number of moves. 


\section{Livelihoods}

As mentioned, migration marked a dramatic increase in the proportion of girls who entered paid work. While only 16 percent of rural girls had ever worked for pay, fully 81 percent of urban migrants had worked for pay, a statistically significant difference ( $p<0.001)$. Urban migrants are more likely to be supporting others financially compared to rural girls. Twenty-seven percent of urban migrants reported that they provide financial support to others compared to 4 percent of rural girls.

\section{Work histories}

We asked urban migrants to talk about the work they had been engaged in over their lifetime, starting with their first paid work (Table 10). The vast majority of girls entered the work world as domestic servants (67 percent), followed by restaurant workers. At the same time, an alarming proportion of girls experienced their first paid work in commercial sex work ( 7 percent). When asked about successive jobs held, while a large proportion of girls entered paid work through domestic service, many did not remain there. Two-thirds of girls' first jobs were in domestic work, while only 38 percent of second jobs and 32 percent of third jobs were in the same field. Entry into the service industry/restaurant/bar work and commercial sex work increased over successive positions. While 14 percent of girls' first jobs were in bars and restaurants, 28 percent of their second and third jobs were in this industry. Likewise, girls' entry into commercial sex work increased, with 17 percent of second jobs and 22 percent of third jobs being in this field.

In the qualitative study, girls reported preferring domestic work for the safety it afforded, particularly away from men who might make advances when they are in other forms of work.

After I got to the city with my friend, the broker suggested I work as a dishwasher, a cook, or a domestic worker. My friend wanted me to get hired in a shisha house and work with her. I wanted to become a domestic worker so I left my friend in Hossana and moved to Addis Ababa. -Commercial sex worker in Adama, age 20, migrated at age 15

I actually would rather work as a domestic worker than in a coffee house. As a domestic worker, you only have to concentrate on the housework, but in the coffee house the men try to talk to you and I hate it.

-Waitress in Dessie, age 18, migrated at age 15, 5 years of education

Table 11 shows the characteristics of the first paid work, by type of position. While domestic work was the most common first work, the earnings from this work were among the lowest. On average, girls in domestic

TABLE 10: Work histories among urban migrants, by type of position

\begin{tabular}{|l|c|c|c|c|}
\hline & $\begin{array}{c}\text { First paid work } \\
(n=3,733)\end{array}$ & $\begin{array}{c}\text { Second paid work } \\
(n=2,106)\end{array}$ & $\begin{array}{c}\text { Third paid work } \\
(\mathrm{n}=920)\end{array}$ & $\begin{array}{c}\text { Fourth paid work } \\
(\mathrm{n}=378)\end{array}$ \\
\hline Domestic worker & 67.0 & 38.3 & 31.8 & 31.2 \\
\hline $\begin{array}{l}\text { Restaurant worker (waitress, } \\
\text { dishwasher, cook) }\end{array}$ & 14.3 & 27.9 & 27.7 & 26.7 \\
\hline Commercial sex worker & 7.3 & 17.3 & 21.7 & 20.1 \\
\hline Petty trader & 2.2 & 4.0 & 3.8 & 5.6 \\
\hline Construction & 1.8 & 2.6 & 2.5 & 1.9 \\
\hline Food/drink production & 1.3 & 2.1 & 3.3 & 3.4 \\
\hline Hair dresser/tailor & 0.9 & 1.1 & 0.5 & 0.5 \\
\hline Farmer & 0.8 & 0.4 & 0.4 & 0.5 \\
\hline Other & 4.5 & 6.4 & 8.2 & 10.1 \\
\hline
\end{tabular}


TABLE 11: Characteristics of first paid work, by type of position $(n=3,733)$

\begin{tabular}{|c|c|c|c|}
\hline & $\begin{array}{l}\text { Age started work } \\
\text { (mean) }\end{array}$ & $\begin{array}{l}\text { Broker involved in } \\
\text { finding work (\%) }\end{array}$ & $\begin{array}{c}\text { Monthly earnings } \\
\text { (mean) }\end{array}$ \\
\hline Domestic worker & 15.2 & 24.5 & ETB 495 \\
\hline Restaurant worker (waitress, dishwasher, cook) & 16.3 & 30.5 & ETB 529 \\
\hline Commercial sex worker & 16.9 & 32.6 & ETB 3,524 \\
\hline Petty trader & 15.8 & 5.1 & ETB 731 \\
\hline Construction & 16.0 & 1.4 & ETB 876 \\
\hline Food/drink production & 16.3 & 22.4 & ETB 500 \\
\hline Hair dresser/tailor & 16.4 & 6.1 & ETB 666 \\
\hline Farmer & 13.6 & 11.1 & ETB 371 \\
\hline Other & 16.5 & 13.9 & ETB 804 \\
\hline
\end{tabular}

work earned ETB 495 per month (US\$22.50), whereas restaurant/bar workers earned an average of ETB 529 (US\$24.00) per month. In comparison, girls in commercial sex work earned considerably more than other categories of paid work, making an average of ETB 3,524 per month, or about US $\$ 160.00$ per month. This earnings pattern is consistent with previous studies of young people in Ethiopia (Erulkar et al. 2010). Perhaps as a result of this, 31 percent of commercial sex workers reported that they would not be able to leave the work, as the pay was too good. Notably, brokers had significant involvement in the placement of girls in commercial sex work, with 33 percent of girls who started in sex work being placed there by brokers.

While domestic workers were among the lowest paid female migrants, they are the category of migrant that was most likely to send home remittances (27 percent). After domestic workers, those who sent home money were bar/ café workers (21 percent), commercial sex workers (18 percent), and migrants in other professions (12 percent).

\section{Conditions of domestic work}

In addition to the extremely low pay, the abusive conditions of domestic work-including sexual exploitationwere echoed throughout many of the interviews with female migrants.

Life was difficult and there were a lot of people around. It was nothing like back home. I had to prepare food constantly, and there were so many clothes to wash. They nagged me and only paid me 200 birr per month, which I got every two months. I left that home without even buying one pair of shoes or new clothes. They also withheld 200 birr from my salary when I left. -Assistant cook in Adama, age 18, migrated at age 15, 6 years of education
I lived there as a domestic worker... I think around 4 months after I started, a boy who was a relative in the household wanted something else from me. It was only him and me in the house during the day. He approached me all the time asking for inappropriate things...you know, he just wanted sex. There were times where he tried to have sex by force...but someone would knock on the door and he would stop.... Do you know what day he raped me? It was August 22, around $5 \mathrm{pm}$, and he came in and closed the door. I wanted to shout, but he covered my mouth. I was just a little girl and he was very huge. His hand was the size of my face. He raped me and he let me go...I was a virgin, 14 years old.... When the owners came home, I told the lady of the house to give me my money, so that I could leave that house. -Commercial sex worker, age 18, migrated at age 14, 7 years of education

When I was in Addis Ababa and my employers were out, my employer's brother-in-law would make advances toward me.... I heard he had HIV.... When I washed clothes he would come by and I didn't understand why he did that. He would always come by when everyone left. He said that he would help me even if he was married, but I did not want anything. I started getting scared.... I told them that I wanted to visit my mother and I left the household. -Tea house worker in Metema, age 20 , migrated at age 17,6 years of education

Virtually all of the reports of sexual abuse in the context of domestic work came from respondents who had since exited the profession. Domestic workers were known not to report the incident, whether to employers, authorities, or in the context of the interview. 
TABLE 12: Context of entry into sex work, by age at entry (percent agreeing with the statement)

\begin{tabular}{|c|c|c|}
\hline & $\begin{array}{l}\text { Below age } 18 \\
\quad(n=386)\end{array}$ & $\begin{array}{l}\text { Age 18+ } \\
(n=412)\end{array}$ \\
\hline \multicolumn{3}{|l|}{ Motivations and context of entry into sex work } \\
\hline $\begin{array}{l}\text { You started sex work to escape other forms of abusive work } \\
\text { such as domestic work. }\end{array}$ & 39.8 & 42.4 \\
\hline You started sex work because you dropped out of school. & $26.7 * *$ & 17.6 \\
\hline $\begin{array}{l}\text { You started sex work to support your children or other family } \\
\text { members. }\end{array}$ & 25.8 & 30.6 \\
\hline You started sex work following the death of parent(s). & 21.7 & 16.9 \\
\hline $\begin{array}{l}\text { You started sex work because you were tricked by an } \\
\text { employer or broker. }\end{array}$ & 20.9 & 17.3 \\
\hline You started sex work after being sexually abused/raped & $17.6 *$ & 11.4 \\
\hline You started sex work following a divorce or widowhood. & 17.0 & $36.6 * * *$ \\
\hline You started sex work to support a drug/alcohol habit. & $16.5 * *$ & 9.0 \\
\hline \multicolumn{3}{|l|}{ Knowledge and encouragement of friends and family } \\
\hline Your family does not know what you do for a living. & 60.5 & 56.7 \\
\hline Your friends encouraged or pressured you to start sex work. & $50.6 *$ & 42.5 \\
\hline Your family members encouraged you to start sex work. & 5.5 & 5.8 \\
\hline
\end{tabular}

Differences between groups significant at $\quad * p<0.05 \quad * * p<0.01 \quad * * * p<0.001$.

Yes, domestic workers don't talk about being sexually abused. They don't speak about it. Due to their culture, the probability of them keeping it a secret is high. -Unlicensed broker from Metema, age 32, 9 years of education

\section{Entry into commercial sex work/commercial sexual exploitation}

Among girls who had engaged in sex for money or support, nearly half (49 percent) started before the age of 18 , while 51 percent started at age 18 or older. Underage sex work is commercial sexual exploitation and is considered to be a form of human trafficking. Among girls who started sex work below the age of 18,44 percent had their first sexual experience in the context of sex work compared to 22 percent of girls who started the work at age 18 or older, a difference that is statistically significant. Table 12 shows the context of initiation into sex work, by the age of entry.

Forty-one percent of commercial sex workers reported that they entered the profession to leave other forms of abusive work such as domestic work. This finding is consistent with previous studies of commercial sex work (Girma and Erulkar 2009) and supports the reportedly abusive conditions of domestic work as well as suggestions that domestic work is a feeder profession for sex work.
I learned that sex work existed after I started working in an areke house. I hated it.... They make you cry when they (commercial sex workers) tell you about themselves. They say their mother died and that they suffered at the hands of their stepmothers. They came here to become a domestic worker and found it hard, so they got into sex work. -Waitress in Addis Ababa, age 18 , migrated at age 12,7 years of education

It is generally the hard domestic work and the abuse that led me into sex work.... I was just fed up with domestic work and I was angry most of the time. I finally decided to start working in this business. -Commercial sex worker in Adama, age 20, migrated at age 15, 5 years of education

Among girls who started below the age of 18 , a significant proportion (27 percent) reported that it was in the context of school leaving, while 37 percent of young women who started at older ages report starting following a divorce or widowhood. About half of the girls in sex work had friends who encouraged them to start; about 5 percent said that families encouraged them to start sex work.

I mean, my friend was actually the one who pushed me into sex work. She told me I would get money out of it.... My eagerness to make money in addition to the push from her got me into the business. -Commercial sex workers in Addis Ababa, age 18, migrated at age 14, 7 years of education 
We tell them that they can improve their lives in a short period of time. We say, "One time I helped two girls find employment as sex workers, and they improved their lives. They both have their own café now, and they are employers themselves. You can achieve the same thing." When she hears us saying this, she starts to think about it and to convince herself. -Unlicensed broker in Adama, age 27, 6 years of education

About one in five girls in sex work started as a result of deception or trickery by an employer or broker (21 percent of girls who started under age 18 and 17 percent of girls who started at age 18 and over). Consistent with this, a number of girls described conditions of coercion and trafficking that led them into sex work.

It was the owner of the hotel in Aksum who took me there. He was saying that I am going to work as a waitress. He exaggerated the issue and, at that time, I thought that the place was near.... He said, "We will go to such-and-such a place. You can return after two days if you don't like it. He made it seem like the

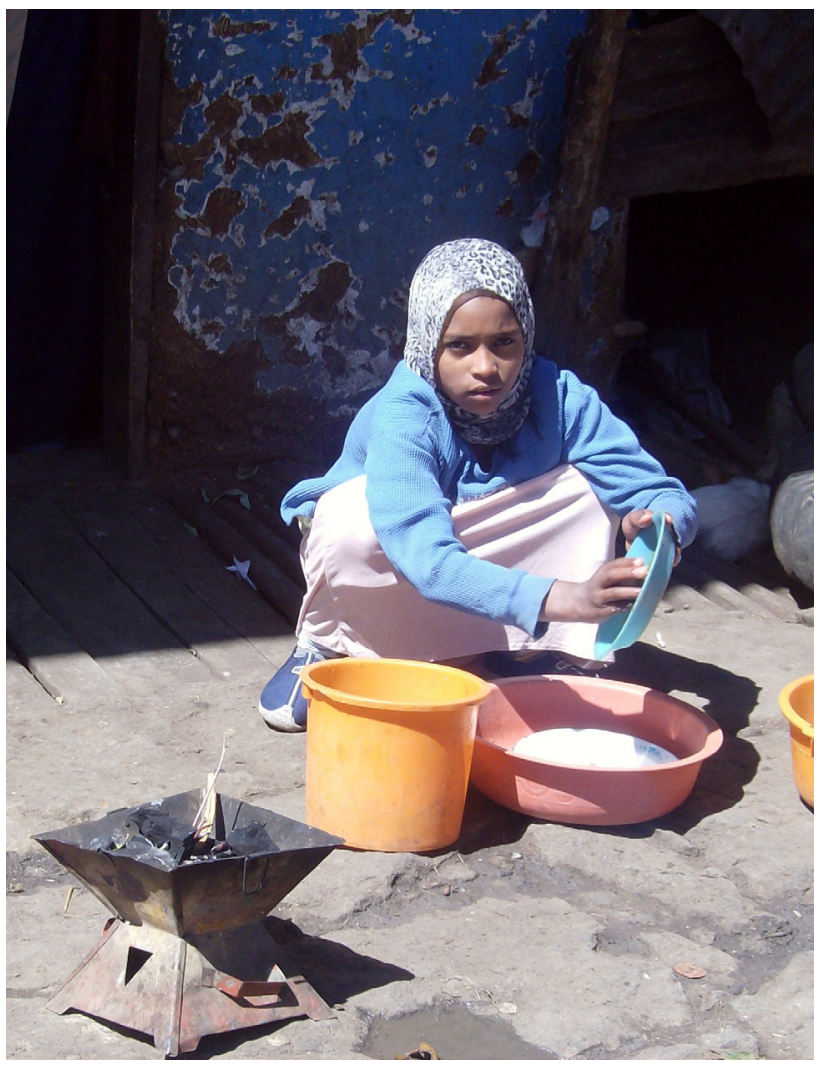

place was not very far and I assumed that the place is only somewhere around Dessie... [On the travel day] it was late when I woke up as I had drunk so much in the evening. He had invited me.... I held only a bag [of belongings] but he told me to leave them home. He said to me that he is going to buy things for me.... It was the owner of the hotel who threatened me. He increased my debt. Even if you have money, he doesn't give it to you in case you want to leave... I found them [co-workers] changing their clothes and grooming themselves. I was amazed at this and I asked to understand the situation/work. They said to me, "He is going to ask you for something..." and then I asked them what it is. They answered, “Oh, don't you know?" And they told me to sit around the entrance of the hotel, and I said OK. I asked them what is going to happen when I sit at the entrance of the hotel. After that, a man asked me if I am with anyone. I thought "What a question?" and I quarreled with him.

-Commercial sex worker, Mekelle, age 20, migrated at age 15,5 years of education 
I was bored with the domestic work and I told him [the broker] to find me work as a waitress, but I told him only at a place that doesn't have beer. He said that there is always beer and he told me that I am going to work as waitress.... The establishment was some kind of small house made of soil...it is just simple and had no toilet, just three rooms. He [the broker] took me to this place and they prepare coffee. He received 60 birr as his broker payment and he left.... Then they tell me to change my clothes. When I ask them why, they asked me if I haven't ever worked such a job before. They said, "If they request you for an overnight, you are going to do as such and such...." I was shocked.... As the woman who owned the establishment was blind, I didn't want to leave her without paying back her 60 birr. There was another boy who was there and he said, "Rather than working here, pay her the debt... let me be your guarantor, and then join a big hotel. I said OK and I joined another hotel which is bigger. -Commercial sex worker, age 20, Mekelle, migrated at age 12,5 years of education

On average, girls in commercial sex work had just over 9 clients in the last week. Among these girls, 10 percent did not use condoms with some of their clients in the last week. Reasons given for not using condoms included that she trusted the client, the client paid more, and the client refused. There were also several reports of violence described by commercial sex workers.

We had a friend who used to work with us... a guy took her for an overnight.... He strangled her with his own tie and she was found dead the next day with the tie around her neck.... After that incident, I decided not to do overnight business anymore. I just do "shorts" now. -Commercial sex workers in Adama, age 20, migrated at age 15, 5 years of education

He agreed to pay me money and I got into his car. He then threatened me with a gun and I was forced to spend the night with him. He left me on the side of the road the next day. -Commercial sex worker in Metema, age 22, migrated at age 14, 5 years of education

It's my friend who got me into sex work; it wasn't on my own. When sex workers save money and visit their relatives, I would say to myself, "How long am I going to live off the handouts of others?" When she said that it was $\mathrm{OK}$ as long as you use a condom, I decided to try it.... But after I got strangled by a client, I stopped. -Tea house worker, Metema, age 20, migrated at age 17,6 years of education
Eight percent of girls reported that they knew of other girls who were not commercial sex workers but who have sex for money and gifts. When asked the occupation of these girls involved in transactional sex, most were reportedly waitresses (36 percent), students (20 percent), jobless (18 percent), or domestic workers (12 percent). 


\section{Sexual Activity}

\section{Levels and context of sexual activity}

Levels of sexual experience varied considerably between different categories of girls (Table 13). While all commercial sex workers were sexually experienced, a large proportion of other migrants (79 percent) and bar/café workers (58 percent) had initiated sex. The lowest percent of girls who were sexually experienced were among rural girls (20 percent) and domestic workers (29 percent). At the same time, it should be recalled that both of these groups were selected from younger age groups: domestic workers from age 15 to 24 and rural girls from age 15 to 17 .
Other than commercial sex workers and bar/café workers, the majority of girls experienced first sex with their spouse. Commercial sex workers, in particular, reported a wide range of first partners including boyfriends (37 percent), spouses (22 percent), strangers (19 percent), and acquaintances (12 percent). Compared to other groups, commercial sex workers were more likely to report first sex with a teacher, employer, or broker.

TABLE 13: Sexual experience, first partner, and context of first sex, by category of respondent

\begin{tabular}{|c|c|c|c|c|c|}
\hline & \multicolumn{4}{|c|}{ URBAN MIGRANTS } & \multirow{2}{*}{$\begin{array}{c}\text { RURAL } \\
\begin{array}{c}\text { Rural girls } \\
(n=732)\end{array}\end{array}$} \\
\hline & $\begin{array}{c}\text { Domestic } \\
\text { workers } \\
(n=1,094)\end{array}$ & $\begin{array}{l}\text { Other urban } \\
\text { migrants } \\
(n=2,289)\end{array}$ & $\begin{array}{l}\text { Commercial } \\
\text { sex workers } \\
(n=796)\end{array}$ & $\begin{array}{l}\text { Bar/café } \\
\text { workers } \\
(n=361)\end{array}$ & \\
\hline \multicolumn{6}{|l|}{ Sexual experience and age at first sex } \\
\hline Ever had sex & 29.1 & 78.5 & 100.0 & 58.2 & 20.4 \\
\hline $\begin{array}{l}\text { Mean age at first sex (among } \\
\text { sexually experienced) }\end{array}$ & 16.8 & 17.0 & 16.0 & 17.3 & 15.1 \\
\hline \multicolumn{6}{|l|}{ First partner } \\
\hline Spouse/partner & 61.6 & 84.4 & 22.4 & 40.7 & 86.6 \\
\hline Boyfriend & 28.0 & 12.2 & 37.2 & 45.9 & 9.4 \\
\hline Acquaintance/neighbor & 2.8 & 1.1 & 12.3 & 4.8 & 0.7 \\
\hline Stranger & 3.1 & 1.5 & 18.9 & 4.3 & 0.7 \\
\hline Other $^{1}$ & 4.5 & 0.8 & 9.2 & 4.3 & 2.6 \\
\hline \multicolumn{6}{|l|}{ Context of first sex } \\
\hline $\begin{array}{l}\text { Given money/gift during first } \\
\text { intercourse }\end{array}$ & 13.8 & 14.5 & 36.4 & 18.7 & 6.0 \\
\hline $\begin{array}{l}\text { Partner would not take “no" for an } \\
\text { answer }\end{array}$ & 19.9 & 13.6 & 24.0 & 13.9 & 25.5 \\
\hline $\begin{array}{l}\text { Physically forced during first } \\
\text { intercourse }\end{array}$ & 19.2 & 9.5 & 21.1 & 14.4 & 17.4 \\
\hline $\begin{array}{l}\text { Hit or beaten during first } \\
\text { intercourse }\end{array}$ & 11.7 & 5.2 & 11.1 & 9.6 & 8.1 \\
\hline $\begin{array}{l}\text { Locked in room or blocked during } \\
\text { first intercourse }\end{array}$ & 6.9 & 3.4 & 9.6 & 6.2 & 4.7 \\
\hline $\begin{array}{l}\text { Had sex against your will as } \\
\text { domestic worker and/or with } \\
\text { employer }\end{array}$ & 4.4 & 1.2 & 6.1 & 5.3 & 0.0 \\
\hline Experienced any form of coercion ${ }^{2}$ & 30.3 & 18.7 & 34.1 & 21.1 & 33.6 \\
\hline
\end{tabular}

1 "Other" includes teacher, employer, broker, relative.

${ }^{2}$ Includes not taking "no" for an answer, physical force, beating, locking in a room, sex against your will. 
18

17.1

17

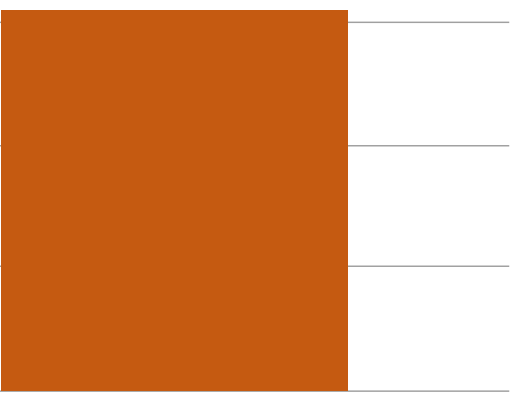

14

16

15.7

15

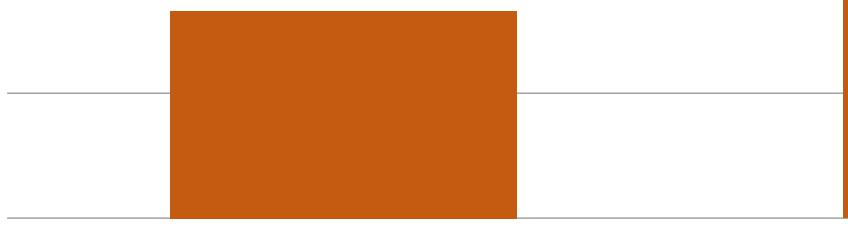

First sex was coerced

First sex was not coerced

\section{Coerced sexual activity}

High levels of coerced first sex were reported among all groups of girls. Seventeen percent of girls reported that their first partner would not take "no" for an answer, while 14 percent reported that first sex was physically forced. We calculated the percent of girls who experienced first sex through any form of coercion. This included not taking "no" for an answer, physical force, use of violence, being locked in a room, and having sex against one's will. Nearly one-quarter (24 percent) experienced sexual initiation under coercive conditions, including 34 percent of commercial sex workers and rural girls and 30 percent of domestic workers. Girls who experienced coerced first sex, experienced sexual initiation at significantly earlier ages than those who did not experience coerced first sex (Figure 3). On average, coerced girls had sexual initiation nearly a year and a half earlier than girls who were not coerced.

Among girls who experienced physically forced sex (both first sex and subsequent sex), only 29 percent told anyone about the experience. The groups least likely to tell anyone about it were rural girls (19 percent), followed by domestic workers (23 percent). Sex workers and bar/café workers were more likely to report the matter (35 percent of sex workers; 37 percent of bar/café workers). The most common people to tell about the incident were female friends (45 percent), mothers (20 percent), police (13 percent), and fathers (12 percent). Only 19 percent of rape victims sought medical assistance following the event and
11 percent sought legal assistance. At the same time, 45 percent reported that they blamed themselves for what happened.

When asked about lifetime partners, there was a significant variation between groups of girls. Rural girls reported the lowest number of lifetime partners (mean 1.4 partners), followed by domestic workers (mean 2.0 partners), other urban migrants (mean 3.6 partners), and bar/café workers (mean 67.5 lifetime partners). While estimates are likely to be flawed, commercial sex workers estimated an average of over 700 lifetime sex partners.

\section{Brokers and sexual activity}

Brokers play a significant role in the transitions of many migrating girls, with involvement in the placement of girls in commercial sex work, work in bar/cafés, and domestic work, among others. Nearly one out of 10 migrant girls (9 percent) reported that a broker tried to have sex with them, and this experience is likely to be underreported.

When brokers were asked about sexual relationships with clients, a considerable proportion-especially of unlicensed brokers-admitted to having sex with their clients (Table 14). Thirty percent of unlicensed brokers and 10 percent of licensed brokers admitted to having had sex with girls they place in jobs. For many girls (43 percent), it was their first time to have sex. Brokers reported that 25 percent of girls did not want to have sex, though this figure is likely to be underreported. The vast majority of girls

\footnotetext{
4. Provision of money and gifts was not used in the calculation, as the question item did not clearly link the provision of money/gift to sexual activity.
} 
TABLE 14: Percent of brokers reporting sexual relationships with female clients $(n=270)$

\begin{tabular}{|c|c|}
\hline & Percentage \\
\hline $\begin{array}{l}\text { Had a sexual relationship with a female } \\
\text { placement in the last two years }\end{array}$ & 22.4 \\
\hline Unlicensed brokers & 30.1 \\
\hline Licensed brokers & 10.5 \\
\hline $\begin{array}{l}\text { Among those having sex with clients } \\
\text { (most recent partner) }\end{array}$ & \\
\hline Was the girl's first time to have sex & 43.3 \\
\hline The girl did not want to have sex & 25.0 \\
\hline $\begin{array}{l}\text { Context of most recent sexual contact } \\
\text { with client }\end{array}$ & \\
\hline Client was a migrant & 98.4 \\
\hline Client was placed in domestic work & 31.7 \\
\hline $\begin{array}{l}\text { Client was placed in the service } \\
\text { industry }\end{array}$ & 61.7 \\
\hline Client had no place to stay & 40.0 \\
\hline A condom was not used & 23.3 \\
\hline
\end{tabular}

were migrants (98 percent), with most of the recent sexual partners having been placed in the service industry (62 percent) or domestic work (32 percent). Among the most recent partners, 40 percent did not have a place to stay, which may suggest that brokers took advantage of girls lacking accommodations. Nearly one-quarter (23 percent) did not use a condom during the last encounter.

Qualitative interviews with brokers also supported that some take advantage of their position to have sex with girls they place:

Girls who migrate pique your interest. She may be a virgin. Something about her makes you interested. There is a saying that goes, "Brokers don't let go of girls without sampling them first." It is true. You invite her for coffee or tea... while you are having coffee or tea together, the time goes. You tell her that you are going to get a room for her and that she is going to sleep there. She will say OK because she has no other option.... If she is unsure, you create some kind of strategy and you try to persuade her, you control her mind.... (I have done this to) 60 girls...I don't know it could be more than this. -Unlicensed broker in Adama, age 32, 9 years of education.

Brokers also reported supporting girls' in their transition. Among the 270 brokers interviewed, 66 percent reported that they had provided girl(s) with financial support and 58 percent said they helped domestic workers with issues concerning their employment including unpaid wages, long work hours, and salary negotiations. 


\section{HIV and AIDS}

While awareness of HIV and AIDS was extensive, specific knowledge about HIV and AIDS was relatively low, especially among rural girls and domestic workers (Table 15). Among different categories of girls we interviewed, only between 53 and 71 percent knew that one cannot get HIV from mosquito bites. Only 31 to 44 percent of girls knew that accidents with sharp objects was not the most common form of transmission. Across all HIV knowledge questions posed, commercial sex workers were consistently the most knowledgeable on the topic; domestic workers and rural girls had the lowest levels of knowledge of HIV. Only one in seven girls gave five correct responses on questions related to HIV knowledge: 24 percent of commercial sex workers, 18 percent of bar/café workers, 16 percent of other urban migrants, 10 percent of domestic workers, and 8 percent of rural girls.

Qualitative interviews reflected domestic workers' limited knowledge of HIV:

A girl from a rural area came for employment as a domestic worker. She told me that urban areas are known to have HIV and asked, "How will I know if the people in the house I will be employed in don't have HIV? What if they touch me when we eat or something?" I laughed and told her HIV is not transmitted through eating and drinking together. I told her HIV is transmitted through sexual intercourse or sharing sharp objects. -Unlicensed broker in Mekelle, age 24, 9 years of education

A considerable proportion of girls (69 percent) had received voluntary counseling and testing (VCT). The greatest proportion of girls receiving the test were commercial sex workers (94 percent), other urban migrants (82 percent), and bar/café workers (74 percent). Only 41 percent of domestic workers and 35 percent of rural girls had ever undergone VCT. The most common places to receive VCT were a health center (47 percent), hospital (20 percent), private clinic (17 percent), NGO facility ( 7 percent), mobile/outreach service (4 percent), and health post and school (2 percent each).

TABLE 15: Awareness and knowledge of HIV and AIDS, by category of respondent

\begin{tabular}{|c|c|c|c|c|c|}
\hline & \multicolumn{4}{|c|}{ URBAN MIGRANTS } & \multirow{2}{*}{$\begin{array}{c}\text { RURAL } \\
\begin{array}{c}\text { Rural girls } \\
(n=732)\end{array}\end{array}$} \\
\hline & $\begin{array}{c}\text { Domestic } \\
\text { workers } \\
(n=1,094)\end{array}$ & $\begin{array}{l}\text { Other urban } \\
\text { migrants } \\
(n=2,289)\end{array}$ & $\begin{array}{l}\text { Commercial } \\
\text { sex workers } \\
(n=796)\end{array}$ & $\begin{array}{l}\text { Bar/café } \\
\text { workers } \\
(n=361)\end{array}$ & \\
\hline Ever heard of HIV and AIDS & 97.2 & 98.6 & 99.9 & 98.9 & 93.3 \\
\hline \multicolumn{6}{|l|}{ HIV Knowledge ${ }^{1}$} \\
\hline $\begin{array}{l}\text { Know that a healthy-looking person } \\
\text { can have HIV }\end{array}$ & 72.6 & 77.7 & 85.0 & 85.2 & 80.4 \\
\hline Know that there is no cure for AIDS & 71.0 & 77.5 & 83.8 & 81.2 & 69.5 \\
\hline $\begin{array}{l}\text { Know that an HIV+ mother can } \\
\text { help protect her unborn child from } \\
\text { HIV }\end{array}$ & 61.3 & 74.2 & 84.1 & 77.6 & 64.7 \\
\hline $\begin{array}{l}\text { Know that one cannot get HIV from } \\
\text { mosquito bites }\end{array}$ & 59.3 & 65.5 & 71.1 & 67.2 & 52.9 \\
\hline $\begin{array}{l}\text { Know that most people do not } \\
\text { get HIV from accidents with sharp } \\
\text { objects }\end{array}$ & 35.3 & 41.6 & 43.9 & 40.3 & 30.9 \\
\hline $\begin{array}{l}\text { Comprehensive knowledge ( } 5 \\
\text { correct responses) }\end{array}$ & 10.3 & 16.4 & 24.1 & 18.2 & 8.4 \\
\hline
\end{tabular}

\footnotetext{
${ }^{1}$ Among those who have heard of HIV and AIDS.
} 
TABLE 16: Awareness of and experience with sexually transmitted infections (STIs) over last 12 months, by category of respondent

\begin{tabular}{|c|c|c|c|c|c|}
\hline & \multicolumn{4}{|c|}{ URBAN MIGRANTS } & \multirow{2}{*}{$\begin{array}{c}\text { RURAL } \\
\begin{array}{c}\text { Rural girls } \\
(n=732)\end{array}\end{array}$} \\
\hline & $\begin{array}{c}\text { Domestic } \\
\text { workers } \\
(n=1,094)\end{array}$ & $\begin{array}{l}\text { Other urban } \\
\text { migrants } \\
(n=2,289)\end{array}$ & $\begin{array}{l}\text { Commercial } \\
\text { sex workers } \\
(n=796)\end{array}$ & $\begin{array}{l}\text { Bar/café } \\
\text { workers } \\
(n=361)\end{array}$ & \\
\hline $\begin{array}{l}\text { Ever heard of other sexually transmit- } \\
\text { ted infections (STIs) }\end{array}$ & 27.1 & 43.5 & 77.7 & 50.3 & 20.2 \\
\hline \multicolumn{6}{|l|}{ Experience with STIs } \\
\hline $\begin{array}{l}\text { Had genital sore/ulcer in the last } \\
12 \text { months }\end{array}$ & 1.4 & 0.7 & 4.3 & 1.7 & 0.3 \\
\hline $\begin{array}{l}\text { Had burning urination or } \\
\text { foul-smelling discharge in the last } \\
12 \text { months }\end{array}$ & 2.1 & 2.2 & 5.6 & 3.1 & 0.8 \\
\hline Had an STI in the last 12 months & 0.5 & 0.7 & 4.9 & 1.7 & 0.4 \\
\hline
\end{tabular}

Table 16 shows levels of awareness and experience with sexually transmitted infections (STIs) in the last 12 months. While the majority of commercial sex workers (78 percent) were aware of STIs, only 20 percent of rural girls and 27 percent of domestic workers were aware. Five percent of commercial sex workers admitted to having had an STI in the last 12 months, while 2 percent of bar/ café workers did the same. That a significant proportion of commercial sex workers reported an STI in the last year is consistent with the earlier finding that 10 percent had not used a condom with at least one of their clients in the last week (see section "Entry into commercial sex work/ commercial sexual exploitation”).

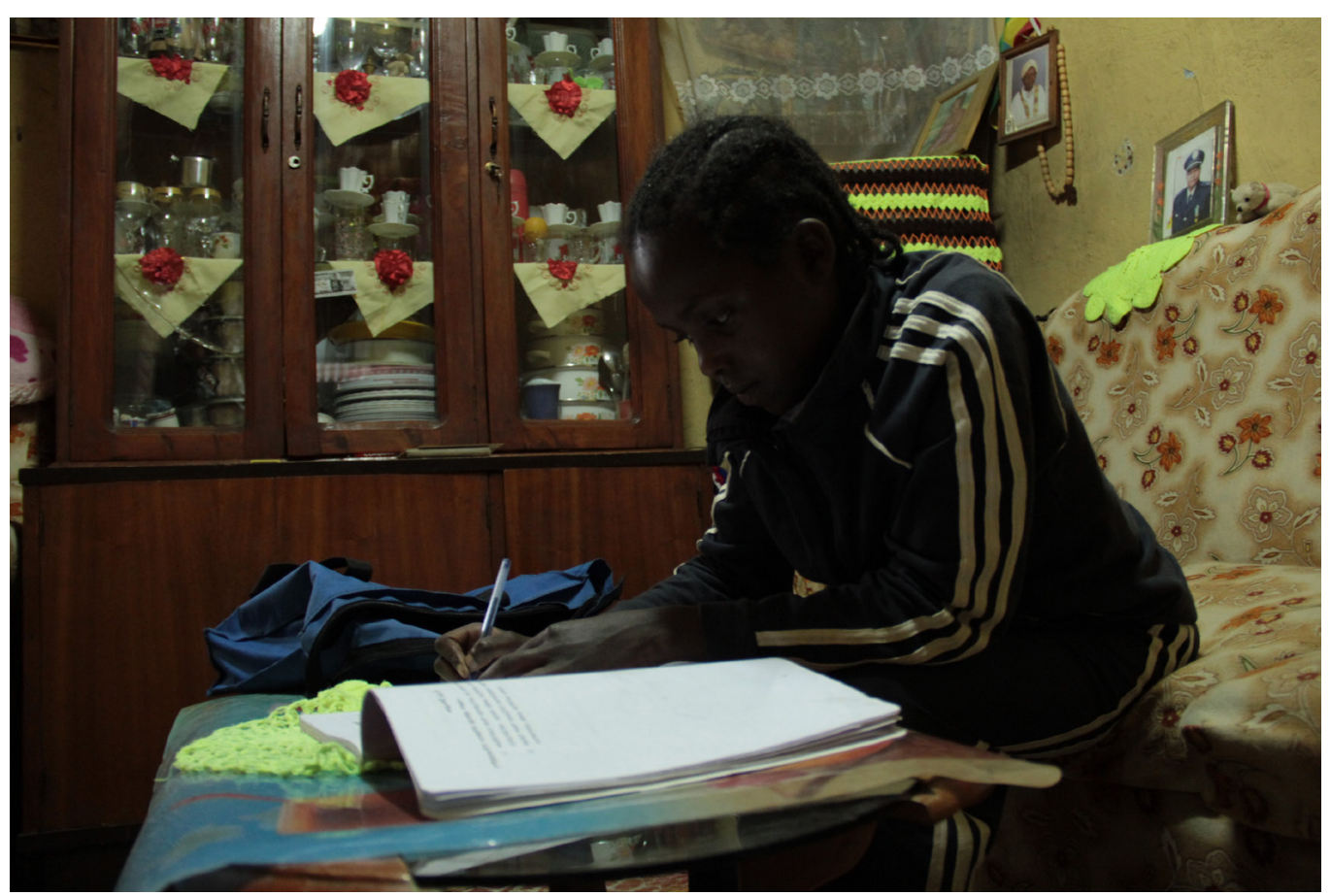




\section{Pregnancy and Childbearing}

Thirty-five percent of the sample had ever been pregnant, ranging from 8 percent of rural girls to 56 percent of other urban migrants and 31 percent of respondents having children (Table 17). Some girls started childbearing from extremely early ages, as young as 11 . Eight percent of girls admitted to having done something to make a pregnancy end. This is particularly common among commercial sex workers with 24 percent admitting to attempting to make a pregnancy end.

While many girls had children, not all were living with their children. Most rural girls (92 percent) and other urban migrants (96 percent) were co-resident with their children. However, among those who had given birth, 48 percent of commercial sex workers and 23 percent of domestic workers and bar/café workers had children who were living elsewhere. Among girls who had given birth, 79 percent had fathers who supported their children, ranging from 91 percent of urban migrants to only 35 percent of commercial sex workers.

TABLE 17: Experience of pregnancy, co-residence, and support for children and ending pregnancy, by category of respondent

\begin{tabular}{|c|c|c|c|c|c|}
\hline & \multicolumn{4}{|c|}{ URBAN MIGRANTS } & \multirow{2}{*}{$\begin{array}{c}\text { RURAL } \\
\begin{array}{c}\text { Rural girls } \\
(n=732)\end{array}\end{array}$} \\
\hline & $\begin{array}{c}\text { Domestic } \\
\text { workers } \\
(n=1,094)\end{array}$ & $\begin{array}{l}\text { Other urban } \\
\text { migrants } \\
(n=2,289)\end{array}$ & $\begin{array}{c}\text { Commercial } \\
\text { sex workers } \\
(n=796)\end{array}$ & $\begin{array}{l}\text { Bar/café } \\
\text { workers } \\
(n=361)\end{array}$ & \\
\hline Ever been pregnant & 14.2 & 56.3 & 35.2 & 17.2 & 7.8 \\
\hline $\begin{array}{l}\text { Ever done anything to make a } \\
\text { pregnancy end }\end{array}$ & 3.3 & 4.8 & 23.7 & 9.7 & 5.3 \\
\hline Has child(ren) & 12.9 & 50.6 & 28.4 & 14.4 & 5.5 \\
\hline \multicolumn{6}{|l|}{ Experience of parenthood $^{1}$} \\
\hline \multicolumn{6}{|l|}{ Co-residence with children } \\
\hline Child(ren) lives with me & 2.1 & 2.2 & 5.6 & 3.1 & 0.8 \\
\hline Child(ren) lives elsewhere & 0.5 & 0.7 & 4.9 & 1.7 & 0.4 \\
\hline Father helps support the child(ren) & 60.7 & 90.9 & 34.5 & 65.4 & 60.0 \\
\hline
\end{tabular}

${ }^{1}$ Among those who have given birth to children. 


\section{Mental Health}

A nine-item patient health questionnaire (PHQ-9) was used to assess the level of depressive symptoms among respondents in the last two weeks. PHQ-9 was initially developed to assess probable depression in the primary care setting (Kroenke, Spitzer, and Williams 2001). It has since been validated in Ethiopian hospitals, primary care settings, and in community and outpatient surveys (Gelaye et. al. 2013; Hanlon et. al. 2015; Fekadu et al. 2016). According to the developers of the tool, it can be scored as a continuous variable or classified as "mild," "moderate," or "severe."

Summary data regarding depressive symptoms is presented in Table 18. The highest prevalence of depressive symptoms is among commercial sex workers (10 percent), followed by bar/café workers (4 percent). The lowest level of depressive symptoms was among rural girls (1 percent). A similar pattern was observed when two core items of PHQ-9 (i.e., anhedonia/inability to feel pleasure and depressed mood) were used as a measure of depression. As the result of elevated depressive symptoms, many respondents experienced much or extreme difficulty in accomplishing everyday tasks: 10 percent of commercial sex workers, 7 percent of bar/café workers, 7 percent of domestic workers, 5 percent of other urban migrants, and 5 percent of rural girls.

Prevalence of elevated depressive symptoms varied by region of residence (Table 19). Among domestic workers, other urban migrants, and bar/café workers, the prevalence of symptoms was highest among residents of Addis Ababa. However, the greatest prevalence of symptoms among commercial sex workers was among residents of Tigray (20 percent) and Amhara (13 percent). In the three regions for which we have data from rural girls-Tigray, Amhara, and Oromia-the prevalence of elevated depressive symptoms was lowest among rural girls in Tigray $(<1$ percent) and similar in Amhara (2 percent) and Oromia (2 percent).

TABLE 18: Prevalence of depressive symptoms in the last 15 days based on PHQ-9, by category of respondent

\begin{tabular}{|c|c|c|c|c|c|}
\hline & \multicolumn{4}{|c|}{ URBAN MIGRANTS } & \multirow{2}{*}{$\begin{array}{c}\text { RURAL } \\
\begin{array}{c}\text { Rural girls } \\
(n=732)\end{array}\end{array}$} \\
\hline & $\begin{array}{c}\text { Domestic } \\
\text { workers } \\
(n=1,094)\end{array}$ & $\begin{array}{c}\text { Other urban } \\
\text { migrants } \\
(n=2,289)\end{array}$ & $\begin{array}{c}\text { Commercial } \\
\text { sex workers } \\
(n=796)\end{array}$ & $\begin{array}{l}\text { Bar/café } \\
\text { workers } \\
(n=361)\end{array}$ & \\
\hline \multicolumn{6}{|c|}{ Severity of depressive symptoms } \\
\hline None or minimal $(0-4)$ & 84.3 & 80.8 & 63.3 & 85.0 & 89.9 \\
\hline Moderate (5-9) & 12.3 & 15.6 & 28.9 & 10.8 & 9.0 \\
\hline Elevated $(10+)$ & 3.5 & 3.6 & 9.8 & 4.2 & 1.1 \\
\hline \multicolumn{6}{|c|}{ Depression (two core PHQ-9 items) } \\
\hline Not depressed & 95.1 & 94.1 & 85.6 & 94.7 & 96.0 \\
\hline Depressed & 4.9 & 5.9 & 14.4 & 5.3 & 4.0 \\
\hline \multicolumn{6}{|c|}{ Difficulty faced in day-to-day activities because of depressive symptoms } \\
\hline No difficulty & 54.4 & 56.2 & 42.6 & 55.3 & 61.6 \\
\hline Some difficulty & 39.2 & 38.8 & 47.6 & 37.7 & 33.6 \\
\hline Much difficulty & 5.8 & 4.4 & 9.1 & 7.0 & 4.2 \\
\hline Extreme difficulty & 0.7 & 0.6 & 0.7 & 0.0 & 0.7 \\
\hline
\end{tabular}


TABLE 19: Regional prevalence of elevated depressive symptoms (PHQ score of 10+) in the last 15 days, by category of respondent and region of residence

\begin{tabular}{|l|c|c|c|c|c|}
\hline & \multicolumn{4}{|c|}{ URBAN MIGRANTS } & RURAL \\
\hline & $\begin{array}{c}\text { Domestic } \\
\text { workers } \\
(\mathrm{n}=1,094)\end{array}$ & $\begin{array}{c}\text { Other urban } \\
\text { migrants } \\
(\mathrm{n}=2,289)\end{array}$ & $\begin{array}{c}\text { Commercial } \\
\text { sex workers } \\
(\mathrm{n}=796)\end{array}$ & $\begin{array}{c}\text { Bar/café } \\
\text { workers } \\
(\mathrm{n}=361)\end{array}$ & $\begin{array}{c}\text { Rural girls } \\
(\mathrm{n}=732)\end{array}$ \\
\hline Tigray & 3.6 & 4.7 & 19.5 & 1.9 & 0.3 \\
Amhara & 4.5 & 3.0 & 12.8 & 3.6 & 1.7 \\
Oromia & 2.8 & 4.1 & 7.6 & 5.2 & 1.6 \\
Harari & 2.0 & 3.5 & 7.6 & 3.9 & - \\
Addis Ababa & 5.6 & 5.1 & 10.7 & 9.4 & - \\
Dire Dawe & 0.8 & 0.8 & 2.0 & 0.0 & - \\
\hline
\end{tabular}

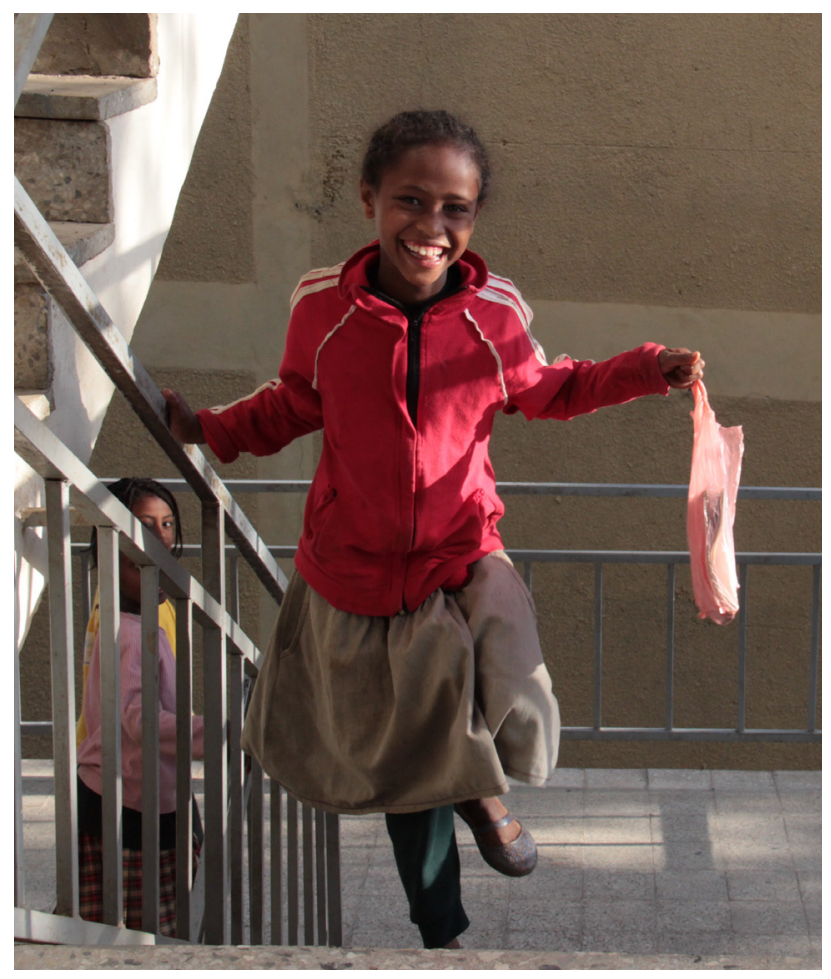




\section{Access to and Utilization of Services}

As described, commercial sex workers displayed the highest level of knowledge of HIV and AIDS (see section "HIV and AIDS"). Not surprisingly, they also reported the greatest level of exposure to sources of HIV information (Figure 4).

Radio was the most common source of information on HIV/AIDS, followed by friends, family members, and service providers. Compared to domestic workers and rural girls, commercial sex workers were more likely to receive HIV information from the radio (71 percent), from a boyfriend/girlfriend (67 percent), and from service providers (51 percent). However, compared to domestic workers and rural girls, they were least likely to receive information from a family member (23 percent of commercial sex workers, compared to 30 percent of domestic workers and 37 percent of rural girls). This could reflect the differential access and relationship that these categories of girls have with family members. Few respondents reported receiving information from employers or brokers.

FIGURE 4: Exposure to HIV information, by source and category of respondent

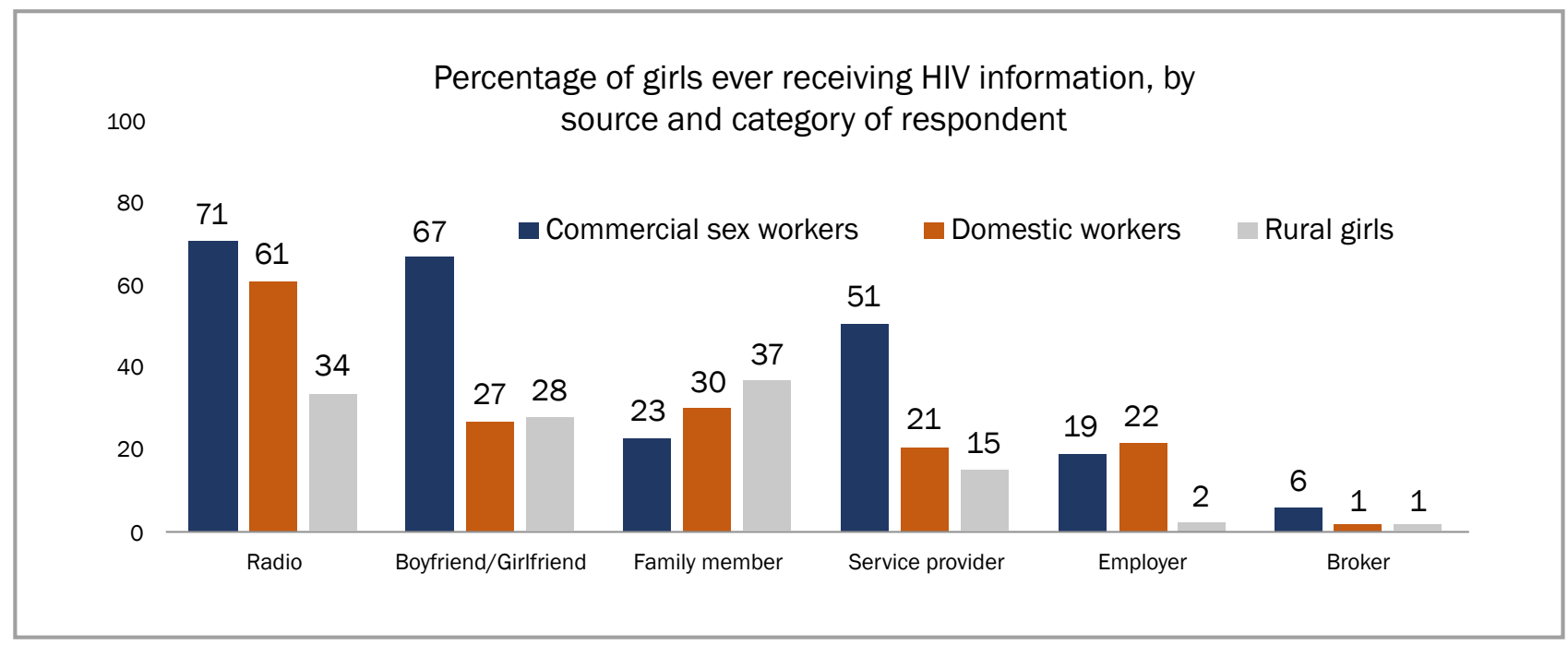

TABLE 20: Percentage of respondents visiting a facility in the last two years, by type of facility and category of respondent

\begin{tabular}{|l|c|c|c|}
\hline & $\begin{array}{c}\text { Commercial } \\
\text { sexworkers } \\
(\mathrm{n}=796)\end{array}$ & $\begin{array}{c}\text { Domestic } \\
\text { workers }(\mathrm{n}=1,094)\end{array}$ & $\begin{array}{c}\text { Rural girls } \\
(\mathrm{n}=732)\end{array}$ \\
\hline Health center & $51.9 * * *$ & 25.3 & 24.1 \\
Private or NGO clinic & $43.0 * * *$ & 20.8 & 17.9 \\
Hospital & $33.6 * * *$ & 23.2 & 14.2 \\
Health post/Health Extension Worker (HEW) & $19.4 * * *$ & 6.9 & 7.5 \\
HIV service & $24.1 * * *$ & 5.8 & 3.0 \\
Youth center/drop-in center & $9.1 * * *$ & 1.6 & 0.7 \\
Youth club & $5.4 * * *$ & 1.1 & 1.9 \\
\hline
\end{tabular}

Differences between groups significant at $* * * p<0.001$. 
Table 20 shows the percent of commercial sex workers, domestic workers, and rural girls who visited different facilities in the last two years. Across all facilities mentioned, commercial sex workers were significantly more likely to visit the facility compared to girls in the other categories.

Qualitative interviews reinforced the finding that commercial sex workers have significant access to programs addressing safe sex:

We have learned [about condom] from the kebele. We have also learned from the police station. In addition, we have learned from WISEUP.... In the previous time, I don't know how to use it, but after they told me, I have learned about it....-Commercial sex worker, Gondar, age 19, 8 years of education

Previously, I used to say what is this "condom thing" and I was not much into it. But during awareness-creation programs, there are meetings for women and I attend them. I learned that if we use a condom correctly, it protects us from many things like STDs, and when I knew that, I loved condoms and I used condoms for work. -Commercial sex worker, age 18, migrated at age 9, 5 years of education 


\section{Discussion and Recommendations}

Compared to other African countries, urbanization in Ethiopia is limited but accelerating rapidly. Out-of-school adolescent girls are some of the main internal migrants in the country. At the same time, the rate of HIV infection among young women aged 20 to 24 is six times that of young men, with indications that urban migrants may be disproportionately affected compared to urban residents who are native to the area. This study of out-of-school girls in Ethiopia focused on experiences of migration and transitions between work roles and different HIV risk profiles and trajectories. The study included both qualitative and quantitative data and took place in six regions of the country. We interviewed different groups of out-of-school rural-urban migrants such as domestic workers, commercial sex workers, bar/café workers, and migrants involved in other professions as well as rural girls, rural parents, and brokers who assisted in the transportation or placement of migrant girls in jobs.

We collected information from 5,272 out-of-school girls and young women in the quantitative survey, including domestic workers, commercial sex workers, bar/café workers, other urban migrants, and rural girls. As well, we interviewed 270 brokers and 688 rural parents. In addition, a large-scale qualitative survey was undertaken to inform the design of the quantitative survey.

Based on reports of out-of-school girls and parents, parent-child communication was limited, especially on sensitive but important areas such as HIV/AIDS and sexual activity. Only 21 percent of out-of-school girls reported that their parents talked to them about HIV and only 11 percent reported discussions on sex. Many young people wished they could talk to their parents more freely (65 percent) and 35 percent said that their parents did not value education.

The average age at migration for girls was just over 14 years. Many made spur of the moment decisions to migrate, often traveling alone. Migration resulted from rural poverty, hardship, school-leaving, and threats of forced early marriages, as well as poor relationships with parents, especially stepparents. Migration brought about radical changes in status, especially in terms of living with parents, schooling status, and working status. The vast majority of out-of-school female migrants went from never having worked for pay in rural areas to working for pay in urban areas, mainly domestic work. While the majority of migrating girls started their working lives in domestic work, many did not continue in this profession. Girls tended to drift from domestic work to work in the service industry to commercial sex work. These transitions could partly have been fueled by abuse and exploitation experienced in domestic work or the lure of much higher earnings in commercial sex work. At the same time, a small but significant proportion of out-of-school girls started their work lives in commercial sex work and one in five commercial sex workers reported that they were tricked or trafficked into the profession.

Out-of-school girls in commercial sex work displayed significantly higher knowledge of HIV/AIDS and reported greater access to health services and information compared to other categories of girls. Commercial sex workers also reported not always using a condom and 5 percent reported having experienced an STI in the previous year. The access of commercial sex workers to different sources of information on HIV/AIDS as well as to an array of services is likely the product of significant efforts by governmental and nongovernmental partners directed at this high-risk group over the past years.

Several recommendations and programmatic implications arise based on these findings:

\section{Additional support and HIV prevention programs for out-of-school girls and young women, migrants, and domestic workers}

Once out-of-school, girls-including migrants and domestic workers-are at high risk of engaging in transactional sex or transitioning into commercial sex work. Moreover the conditions of migration and domestic work put girls at risk of sexual abuse and exploitation, and resulting infection with HIV. However, these categories of out-ofschool girls are largely ignored by HIV prevention efforts. 
More programs are needed to provide support and safety to out-of-school girls, especially social assets, information, services, and protection for migrants and domestic workers. Programs targeted to the time of migration are also recommended as this represents a point of extreme vulnerability for out-of-school girls.

\section{Programs for commercial sex workers to in- crease focus on recent entrants and address violence}

Commercial sex workers who are new to the profession were most likely not to use protection and to be exploited. Programs for these girls and young women should increase protection and support to recent entrants into the profession, including devising strategies to chart alternative livelihoods. In addition, girls and young women working in commercial sex work reported significant levels of violence, which put their lives at risk and which was often the reason for not using condoms. However, support programs were not described as addressing violence faced in this line of work. While CSWs reported that they felt protected by law enforcement, additional efforts are needed to address violence against girls and women and punish perpetrators and clients.

\section{Programs to address exploitation and abuse of out-of-school girls and domestic workers, including sexual exploitation}

A significant number of former domestic workers described previous experiences of sexual abuse in the context of domestic work. Many described moving from domestic work to commercial sex work or transactional sex to escape the poor working conditions and/or sexual abuse. It was also widely believed that domestic workers do not talk about such abuse while still in the profession, but only divulge the information after leaving the profession. There were indications that domestic work may be a feeder profession for commercial sex work, partly due to abuse and exploitation and partly due to the narrow range of work options available to out-of-school girls. Ethiopia has not ratified the Domestic Worker Convention (C189), which calls for enforcement of minimum age of employment, a minimum wage for domestic workers, and decent working hours and conditions, among others (ILO 2011). Programs should raise awareness on the rights of domestic workers and actively promote provisions in the Convention.
Provide safe and productive livelihoods skills for out-of-school girls and women

Girls from rural areas are educationally disadvantaged and have limited livelihoods opportunities in urban areas. Many resort to transactional sex as an economic support strategy. Support programs should build girls' skills in safe and productive livelihoods, facilitating their exit from unsafe forms of work such as domestic work and sex work as well as transactional sex. Financial literacy and entrepreneurship training can provide out-of-school girls with the skills necessary to transit into safer forms of work, such as petty trade and other small businesses. As well, expanded educational opportunities-including increased access and improvements in quality of education-in both rural and urban areas are important to give girls the grounding necessary to be competitive in the labor force as well as increase their access to health services.

\section{Increased attention to trafficking (not just across international borders)}

Much attention has been focused in Ethiopia on the international "maid trade" and cross-border migration, smuggling, and trafficking (UNICEF 2017). Our research suggests that a considerable number of girls within Ethiopia are victims of deception, coercion, and trafficking into domestic work, sex work, or other professions. Out-of-school girls described being promised schooling in the urban areas or well-paying professional jobs, only to find themselves far away from home and anything familiar, working as a commercial sex worker in a hotel, and sometimes indebted to the owner of the establishment. Brokers frequently play an important part in these events. Little attention has been paid to such circumstances in the context of internal migration, and increased programmatic attention to internal trafficking, including the role of brokers, is warranted. 


\section{References}

Casacchia, O., M. Crisci, and C. Reynaud. 2001. “Internal Migration in Ethiopia," in Migration and Urbanization in Ethiopia with Special Reference to Addis Ababa. Addis Ababa: University of Rome and Central Statistical Authority.

De Regt, M. 2016. “Time to look at girls: Adolescent girls' migration in Ethiopia." Unpublished report. May.

Erulkar, A., A. Ferede, W. Ambelu, et al. 2010. "Ethiopia Young Adult Survey: A Study in Seven Regions." Addis Ababa: Population Council and UNFPA. September.

Erulkar, A. and T. Mekbib. 2007. "Invisible and vulnerable: Adolescent domestic workers in Addis Ababa, Ethiopia." Vulnerable Child and Youth Studies 2(3): 246-256.

Erulkar, A., T. Mekbib, N. Simie, and T. Gulema. 2006 “Migration and vulnerability among adolescents in slum areas of Addis Ababa, Ethiopia," Journal of Youth Studies 9(3): 361-374.

Ezra, M. 2001. "Ecological degradation, rural poverty, and migration in Ethiopia: A contextual analysis," Policy Research Division Working Paper. New York: Population Council.

Federal HIV AIDS Prevention and Control Office (FHAPCO). 2014. "Country Progress Report on the HIV Response, 2014: Federal Democratic Republic of Ethiopia." Addis Ababa: FHAPCO. March.

Fekadu, A., G. Medhin, M. Selamu, et al. 2016. “Non-fatal suicidal behaviour in rural Ethiopia: A cross-sectional facility- and population-based study," BMC Psychiatry (2016) 16:75.

Gebre, Y., A. Gebre, R. Shiferaw, and H. Workineh. 2012. "Resilience in children exposed to sexual abuse and sexual exploitation in Merkato, Addis Ababa, Ethiopia." Research report submitted to the OAK Foundation.

Gelaye, B., M.A. Williams, S. Lemma, et al. 2013. “Diagnostic validity of the composite international diagnostic interview (CIDI) depression module in an East African population," International Journal of Psychiatry in Medicine 46(4): 387-405.

Girma, W. and A. Erulkar, 2009. "Commercial sex workers in five Ethiopian cities: A baseline survey for targeted HIV prevention for most-at-risk populations." Addis Ababa: Population Council. Report, September.

Hanlon, C., G. Medhin, M. Selamu, et al. 2015. "Validity of brief screening questionnaires to detect depression in primary care in Ethiopia," Journal of Affective Disorders 186: 32-39.

International Labour Organization (ILO). 2011. C189-Domestic Workers Convention, 2011 (No. 189). Geneva: ILO. June.
Kroenke, K., R.L. Spitzer, and J.B. Williams. 2001. "The PHQ9: Validity of a brief depression severity measure," Journal of General Internal Medicine 16(9): 606-613.

Temin, M., M. Montgomery, S. Engebretsen, and K. Barker. 2013. "Girls on the move: Adolescent girls \& migration in the developing world.” New York: Population Council.

UNICEF. 2017. "A child is a child: Protecting children on the move from violence, abuse and exploitation." New York: UNICEF. May.

van Blerk, L. 2008. "Poverty, migration and sex work: Youth transition in Ethiopia.” Area 40, No. 2: 245-253.

World Bank. 2010. The Ethiopian urban migration study 2008: The characteristics, motivations and outcomes of migrants to Addis Ababa, World Bank Poverty Reduction and Economic Management. August.

World Bank Group. 2016. World Bank Open Data. http://data.worldbank.org/country/ethiopia, Accessed March 10, 2016. 